NBER WORKING PAPER SERIES

\title{
HOW DO MONETARY AND FISCAL POLICY INTERACT IN THE EUROPEAN MONETARY UNION?
}

\author{
Matthew B. Canzoneri \\ Robert Cumby \\ Behzad Diba \\ Working Paper 11055 \\ http://www.nber.org/papers/w11055 \\ NATIONAL BUREAU OF ECONOMIC RESEARCH \\ 1050 Massachusetts Avenue \\ Cambridge, MA 02138 \\ January 2005
}

Prepared for the NBER's ISOM in Reykjavik, Iceland, June 18-19, 2004. The views expressed herein are those of the author(s) and do not necessarily reflect the views of the National Bureau of Economic Research.

(C) 2005 by Matthew B. Canzoneri, Robert Cumby, and Behzad Diba. All rights reserved. Short sections of text, not to exceed two paragraphs, may be quoted without explicit permission provided that full credit, including (C) notice, is given to the source. 
How Do Monetary and Fiscal Policy Interact in the European Monetary Union?

Matthew B. Canzoneri, Robert Cumby, and Behzad Diba

NBER Working Paper No. 11055

January 2005

JEL No. E63, F33

\section{ABSTRACT}

Formation of the Euro area raises new questions about the coordination of monetary and fiscal policy. Using a New Neoclassical Synthesis (NNS) model, we show that a common monetary policy, responding to area-wide aggregates, has asymmetric effects on countries within the union, depending on whether they are large or small, or whether they have high or low debts. We analyze the implications of these asymmetries for the various countries welfare and for their fiscal policies. We also study rules for setting national tax and spending rates, rules that constrain movements in the deficit to GDP ratio. We ask whether these rules are necessary for the common monetary policy to be able to harmonize national inflation rates, and we analyze their effects on national welfare. We also discuss some potential failings of our model (and perhaps NNS models generally); in particular, our model's variance decompositions suggest that productivity shocks may play an inordinately large role, while fiscal shocks (or demand shocks generally) may play too small a role (even when 'rule of thumb' spenders are added).

Matthew B. Canzoneri

Department of Economics

Georgetown University

Washington, DC 20057

canzonem@georgetown.edu

Robert E. Cumby

Department of Economics

Georgetown University

Washington, DC 20057

and NBER

cumbyr@goergetown.edu
Behzad T. Diba

Department of Economics

Georgetown University

Washington, DC 20057

dibab@georgetown.edu 


\section{Introduction}

Formation of the Euro area raises new questions about the coordination of monetary and fiscal policy. Twelve countries - each with its own tax and spending policies - are now married by a common monetary policy. Does the common monetary policy have the same effect in each of the countries, and the same implications for fiscal policy? Or, does it affect high debt countries in a different way than low debt countries? Does it favor big countries over small countries? And, how does the existence of twelve separate fiscal policies affect the European Central Bank's (ECB) ability to control inflation? In particular, is the lack of coordination of national fiscal policies a major source of the rather surprising diversity of national inflation rates we have observed since the Euro's inception? And, is the consequent diversity of national real interest rates a source of macroeconomic instability? If so, does this point to a need for constraints on deficits, as embodied in the Stability and Growth Pact (SGP)? Or, does the SGP itself create a new source of instability at the national level?

In this paper, we try to address these questions within the context of the New Neoclassical Synthesis (NNS). ${ }^{1}$ The NNS is characterized by optimizing agents and some form of nominal inertia. Thus, the NNS provides a natural framework to study the interactions between monetary and fiscal policy: its neoclassical underpinnings allow us to analyze the positive and normative implications of distortionary taxation, while its assumption of nominal inertia allows us to assess the implications of these microeconomic aspects of fiscal policy for macroeconomic stability.

The NNS has been used extensively to analyze monetary policy. ${ }^{2}$ Integrating fiscal policy

${ }^{1}$ Goodfriend and King (1997) outlined the New Neoclassical Synthesis, and gave it the name. Woodford (2003) provides a masterful introduction to this class of models.

${ }^{2}$ See Clarida, Gali and Gertler (1999) and Canzoneri, Cumby and Diba (2003). 
has however been slow. There have been papers analyzing the theory of optimal monetary and fiscal policy, ${ }^{3}$ but quantitative analyses are scarce. ${ }^{4}$ There is, of course, a reason for this. It has been difficult to make NNS models replicate stylized facts about fiscal policy, facts that are taken from the recent empirical literature. We will discuss some potential problems with our current modeling effort, and it should be admitted at the outset that these problems may be driving some of our results. In this sense, we view our paper as the beginning of a research agenda, and not as the final word on policy coordination within a monetary union.

We do not attempt a serious calibration to any particular country; instead, we calibrate a series of models that seem to capture important aspects of the interaction between monetary and fiscal policy in the Euro area. An empirical investigation of the relationship between the aggregate Euro area inflation rate and national inflation rates, and various aspects of fiscal policy within the Euro area, suggests that we calibrate our model to an "Average" (small) Country, a High Debt Country, and a Large Country. Then, we ask how the common monetary policy impinges on national fiscal policy and national welfare in each of these 'countries', and how uncoordinated national fiscal policies impinge on the ECB's ability to control inflation. We show that the common monetary policy has asymmetric effects on the three countries: the effects differ between the Average Country and the High Debt Country (not too surprisingly) because the latter's fiscal position is more sensitivity to changes in debt payments, and the effects differ between the Average Country and the Large Country (perhaps more surprisingly) because the latter's inflation rate is more

${ }^{3}$ Examples include Benigno and Woodford (2003), Kollmann (2003), and Uribe and Schmitt-Grohe (2003, 2004).

${ }^{4}$ Duarte and Wolman (2002) is a notable example; we will discuss their work below. 
highly correlated with aggregate Euro area inflation.

It may be best to summarize our basic results for the coordination of monetary and fiscal policy at the outset:

- Productivity shocks and idiosyncratic monetary policy shocks explain $70 \%$ of the volatility in the deficit-to-GDP ratio in our Average and Large Countries, and 80\% in our High Debt Country. Rules (like the SGP) that try to discipline fiscal policy by requiring governments to limit the unconditional standard deviation of the debt-to-GDP ratio seem rather perverse in this context.

- Productivity shocks are the dominant source of inflation differentials in all versions of our model, followed by idiosyncratic monetary policy shocks. Shocks to tax rates and spending play a minor role. These results are not changed by the inclusion of 'rule of thumb' consumers (which augments the effect of fiscal shocks on aggregate demand). The large inflation differentials observed in the Euro area do not, according to our models, point to the need for coordination of national fiscal policies.

- Our model suggests that if constraints on deficits are deemed necessary in the Euro area, then there are advantages to doing so by requiring that government purchases, rather than the wage tax rate, respond to the deficit. In fact, our model suggests that such a constraint may actually be welfare enhancing, since government spending crowds out private consumption in our model. But as we discuss below, this result may be driven by problematic features of our model.

- Deficits are more sensitive to interest rates in high debt countries, due to the burden of debt service. In addition, high debt countries tend to have higher tax rates, increasing tax 
distortions, and making tax revenues more sensitive to changes in the tax base. Not surprisingly, these factors lead to welfare costs: the typical household in our High Debt Country would be willing give up $1.3 \%$ percent of its consumption each period to live in the Average Country.

- Our model suggests that the common monetary policy favors larger countries in the Euro area, since their inflation rates are more highly correlated with aggregate (Euro area) inflation. For example, the welfare cost of business cycles in our Average Country is four times larger than in our Large Country.

As noted earlier, some of these results may be driven by potential weaknesses in our NNS modeling. In particular, the role played by productivity shocks appears to be excessive in our models. And, an increase in government purchases crowds out private consumption; this is inconsistent with empirical work by Fatas and Mihov (2000, 2001), Blanchard and Perotti (2002) and Canzoneri, Cumby and Diba (2002). In an attempt to address the consumption paradox, and to enhance the role of demand side shocks, we add 'rule of thumb' consumers in the last section of the paper. However, this experiment in NNS modeling does not change any of our basic conclusions. The rest of the paper is organized as follows: In Section 2, we outline our basic NNS framework and explain how we calculate national welfare; then, we present an empirical analysis that documents various aspects of fiscal policy in the Euro area and how movements in national inflation rates affect the aggregate Euro area inflation rate; and finally, on the basis of this empirical analysis, we calibrate our model for an Average Country, a High Debt Country and a Large Country. In Section 3, we provide an overview of the performance of each version of the model, focusing especially on the role of productivity shocks. In Section 4, we explain why the common monetary 
policy has asymmetric affects across the Euro area, and we discuss the ways in which it impinges upon national fiscal policy and welfare. Some people believe that constraints on the size of deficits are necessary in a monetary union; so, in Section 5, we discuss rules for the wage tax or government spending which limit fluctuations in the deficit to GDP ratio; we assess their positive and normative

effects. In Section 6, we discuss the ways in which fiscal policy impinges on the ECB's ability to control inflation across the Euro area, and the possible need for fiscal constraint to control inflation differentials across the Euro area; we also discuss some anomalies in the way changes government purchases affect private consumption and investment. In Section 7, we introduce 'rule of thumb' agents to try to address some of those anomalies. And in Section 8, we conclude with a discussion of future research.

\section{A Model of Euro Area Economies}

We begin in Section 2.A with a description of the basic theoretical framework. In Section 2.B, we provide an empirical analysis of national inflation differentials, and of national tax and spending policies. We draw on this empirical work to calibrate a benchmark model to our three typical country profiles: a typical small country, a typical high debt country, and a typical large country. In the remainder of the paper, we use the model to discuss the interaction between monetary and fiscal policy in the Euro area.

\section{A. The Theoretical Framework}

Like other NNS models, our model is characterized by optimizing agents, monopolistic competition, and nominal inertia. Our basic framework is most closely related to those in Erceg, Henderson and Levin (2000) and Collard and Dellas (2003): as in Collard and Dellas (2003), we allow for capital accumulation, and we calculate second order approximations to both the model and 
the welfare function; as in Erceg, Henderson and Levin (2000), we allow for both wage and price inertia. Our framework differs from theirs in that we introduce distortionary taxation (on consumption and labor income) and debt dynamics.

\section{A.1. Firms' price setting behavior -}

There is a continuum of firms - indexed by $\mathrm{f}-$ on the unit interval. At time $\mathrm{t}$, each firm rents capital $\mathrm{K}_{t-1}(\mathrm{f})$ at the rate $\mathrm{R}_{\mathrm{t}}$, hires a labor bundle $\mathrm{N}_{\mathrm{t}}(\mathrm{f})$ at the rate $\mathrm{W}_{\mathrm{t}}$, and produces a differentiated $\operatorname{product}^{5}$

(1) $Y_{t}(f)=Z_{t} K_{t-1}(f)^{v} N_{t}(f)^{v-1}$,

where $0<v<1$, and $Z_{t}$ is an economy wide productivity shock that follows an autoregressive process $-\log \left(Z_{\mathrm{t}}\right)=\rho \log \left(\mathrm{Z}_{\mathrm{t}-1}\right)+\epsilon_{\mathrm{p}, \mathrm{t}}$. The firm's cost minimization problem implies

(2) $\mathrm{R}_{\mathrm{t}} / \mathrm{W}_{\mathrm{t}}=[v /(1-v)]\left(\mathrm{N}_{\mathrm{t}}(\mathrm{f}) / \mathrm{K}_{\mathrm{t}-1}(\mathrm{f})\right)$,

and the firm's marginal cost can be expressed as

(3) $\mathrm{MC}_{\mathrm{t}}(\mathrm{f})=\left[v^{v}(1-v)^{(1-v)}\right]^{-1} \mathrm{R}_{\mathrm{t}}^{v} \mathrm{~W}_{\mathrm{t}}^{1-v} / \mathrm{Z}_{\mathrm{t}}$.

A composite good

(4) $Y_{t}=\left[\int_{0}^{1} Y_{t}(f)^{(\phi p-1) / \phi p} d f\right]^{\phi p /(\phi p-1)}, \phi_{p}>1$,

can be used as either a consumption good or capital. The good's price, which can be interpreted as the aggregate price level, is given by

(5) $\mathrm{P}_{\mathrm{t}}=\left[\int_{0}^{1} \mathrm{P}_{\mathrm{t}}(\mathrm{f})^{1-\phi p} \mathrm{df}\right]^{1 /(1-\phi p)}$,

and demand for the product of firm $\mathrm{f}$ is given by

(6) $Y_{t}^{d}(f)=\left(P_{t} / P_{t}(f)\right)^{\phi p} Y_{t}$.

${ }^{5}$ Although the aggregate capital stock will be predetermined in our model, we are assuming that capital is mobile across firms. Thus, in our notation, $\mathrm{K}_{\mathrm{t}-1}(\mathrm{f})$ stands for firm $\mathrm{f}^{\prime} \mathrm{s}$ choice of its capital input at time $t$. 
Following Calvo (1983), firms set prices in staggered 'contracts' of random duration. In any period $t$, each firm gets to announce a new price with probability (1- $\alpha)$; otherwise, the old contract, and its price, remains in effect. If firm $f$ gets to announce a new contract in period $t$, it chooses a new price $P_{t}^{*}(f)$ to maximize the value of its profit stream over states of nature in which the new price is expected to hold:

(7) $\mathrm{E}_{\mathrm{t}} \sum_{\mathrm{j}=\mathrm{t}}^{\infty}(\alpha \beta)^{\mathrm{j}-\mathrm{t}} \lambda_{\mathrm{j}}\left[\mathrm{P}_{\mathrm{t}}^{*}(\mathrm{f}) \mathrm{Y}_{\mathrm{j}}(\mathrm{f})-\mathrm{TC}_{\mathrm{j}}(\mathrm{f})\right]$,

where TC(f) is the firm's total cost, $\beta$ is the households' discount factor, and $\lambda_{\mathrm{j}}$ is the households' marginal utility of nominal wealth (to be defined below). The firm's first order condition is

(8) $\mathrm{P}_{\mathrm{t}}^{*}=\mu_{\mathrm{p}}\left(\mathrm{PB}_{\mathrm{t}} / \mathrm{PA}_{\mathrm{t}}\right)$,

where $\mu_{\mathrm{p}}=\phi_{\mathrm{p}} /\left(\phi_{\mathrm{p}}-1\right)$ is a monopoly markup factor, and

(9) $\mathrm{PB}_{\mathrm{t}}=\mathrm{E}_{\mathrm{t}} \sum_{\mathrm{j}=\mathrm{t}}^{\infty}(\alpha \beta)^{\mathrm{j}-\mathrm{t}} \lambda_{\mathrm{j}} \mathrm{MC}_{\mathrm{j}}(\mathrm{f}) \mathrm{P}_{\mathrm{j}}^{\phi p} \mathrm{Y}_{\mathrm{j}}=\alpha \beta \mathrm{E}_{\mathrm{t}} \mathrm{PB}_{\mathrm{t}+1}+\lambda_{\mathrm{t}} \mathrm{MC}_{\mathrm{t}}(\mathrm{f}) \mathrm{P}_{\mathrm{t}}^{\phi p} \mathrm{Y}_{\mathrm{t}}$

(10) $\mathrm{PA}_{\mathrm{t}}=\mathrm{E}_{\mathrm{t}} \sum_{\mathrm{j}=\mathrm{t}}^{\infty}(\alpha \beta)^{\mathrm{j}-\mathrm{t}} \lambda_{\mathrm{j}} \mathrm{P}_{\mathrm{j}}^{\phi p} Y_{\mathrm{j}}=\alpha \beta \mathrm{E}_{\mathrm{t}} \mathrm{PA} \mathrm{A}_{\mathrm{t}+1}+\lambda_{\mathrm{t}} \mathrm{P}_{\mathrm{t}}^{\phi p} Y_{\mathrm{t}}$

As $\alpha \rightarrow 0$, all firms reset their prices each period (the flexible price case), and $\mathrm{P}_{t}^{*}(\mathrm{f}) \rightarrow \mu_{\mathrm{p}} \mathrm{MC}_{\mathrm{t}}(\mathrm{f})$. Since the markup is positive $\left(\mu_{\mathrm{p}}>1\right)$, output will be inefficiently low in the flexible price solution.

\section{A.2. Households' wage setting behavior and capital accumulation-}

There is a continuum of households indexed by $\mathrm{h}$ on the unit interval. Each household supplies a differentiated labor service to all of the firms in the economy. The composite labor bundle

(11) $\mathrm{N}_{\mathrm{t}}=\left[\int_{0}^{1} \mathrm{~L}_{\mathrm{t}}(\mathrm{h})^{(\phi \mathrm{w}-1) / \phi \mathrm{w}} \mathrm{dh}\right]^{\phi \mathrm{w} /(\phi \mathrm{w}-1)}, \phi_{\mathrm{w}}>1$, reflects the firms' production technology. Cost minimization implies that the bundle's wage is (12) $\mathrm{W}_{\mathrm{t}}=\left[\int_{0}^{1} \mathrm{~W}_{\mathrm{t}}(\mathrm{h})^{1-\phi w} \mathrm{dh}\right]^{1 /(1-\phi w)}$, and demand for the labor of household $\mathrm{h}$ is 
(13) $\mathrm{L}_{\mathrm{t}}^{\mathrm{d}}(\mathrm{h})=\left(\mathrm{W}_{\mathrm{t}} / \mathrm{W}_{\mathrm{t}}(\mathrm{h})\right)^{\phi \mathrm{w}} \mathrm{N}_{\mathrm{t}}$.

The utility of household $\mathrm{h}$ is

(14) $\mathrm{U}_{\mathrm{t}}(\mathrm{h})=\mathrm{E}_{\mathrm{t}} \sum_{\tau=\mathrm{t}}^{\infty} \beta^{\tau-\mathrm{t}}\left[\log \left(\mathrm{C}_{\tau}(\mathrm{h})\right)-(1+\chi)^{-1} \mathrm{~L}_{\tau}(\mathrm{h})^{1+\chi}\right]$

where $C_{t}(h)$ is household consumption of the composite good, and the second term on the RHS of (14) reflects the household's disutility of work. ${ }^{6}$ The household's budget constraint is

$$
E_{t}\left[\Delta_{t, t+1} B_{t+1}(h)\right]+P_{t}\left[\left(1+\tau_{c, t}\right) C_{t}(h)+I_{t}(h)+T_{t}\right]=B_{t}(h)+\left(1-\tau_{w, t}\right) W_{t}(h) L_{t}^{d}(h)+R_{t} K_{t-1}(h)+D_{t}(h)
$$

where the first term on the LHS is a portfolio of contingent claims; $\mathrm{I}_{\mathrm{t}}$ is the household's investment in capital; $\mathrm{T}_{\mathrm{t}}$ represents lump sum taxes and transfers; $\tau_{\mathrm{c}, \mathrm{t}}$ and $\tau_{\mathrm{w}, \mathrm{t}}$ are the tax rates on consumption and labor, and the last three terms on the RHS are the household's wage, rental and dividend income. The household's capital accumulation is governed by

$(16) \mathrm{K}_{\mathrm{t}}(\mathrm{h})=(1-\delta) \mathrm{K}_{\mathrm{t}-1}(\mathrm{~h})+\mathrm{I}_{\mathrm{t}}(\mathrm{h})-1 / 2 \psi\left[\left(\mathrm{I}_{\mathrm{t}}(\mathrm{h}) / \mathrm{K}_{\mathrm{t}-1}(\mathrm{~h})\right)-\delta\right]^{2} \mathrm{~K}_{\mathrm{t}-1}(\mathrm{~h})$,

where $\delta$ is the depreciation rate, and the last term is the cost of adjusting the capital stock.

Household h maximizes utility, (14), subject to its budget constraint, (15), its labor demand curve, (13), and its capital accumulation constraint, (16). We begin with the wage setting decision. Following Calvo (1983), households set wages in staggered 'contracts' of random duration. In any period $t$, each household gets to announce a new wage with probability (1- $\omega)$; otherwise, the old contract, and its wage, remains in effect.

If household $\mathrm{h}$ gets to announce a new contract in period $\mathrm{t}$, it chooses the new wage (17) $\mathrm{W}_{\mathrm{t}}^{* 1+\phi w \chi}=\mu_{\mathrm{w}}\left(\mathrm{WB}_{\mathrm{t}} / \mathrm{WA}_{\mathrm{t}}\right)$,

${ }^{6}$ The utility function (and budget constraint below) should also include a term in real money balances, but we follow much of the NNS literature in assuming that this term is negligible. An interest rate rule characterizes monetary policy, so there is no need to model money explicitly. 
where $\mu_{\mathrm{w}}=\phi_{\mathrm{w}} /\left(\phi_{\mathrm{w}}-1\right)$ is a monopoly markup factor, and

(18) $\mathrm{WB}_{\mathrm{t}}=\mathrm{E}_{\mathrm{t}} \sum_{\mathrm{j}=\mathrm{t}}^{\infty}(\omega \beta)^{\mathrm{j}-\mathrm{t}} \mathrm{N}_{\mathrm{j}}^{1+\chi} \mathrm{W}_{\mathrm{j}}^{\phi \mathrm{w}(1+\chi)}=\omega \beta \mathrm{E}_{\mathrm{t}} \mathrm{WB}_{\mathrm{t}+1}+\mathrm{N}_{\mathrm{t}}^{1+\chi} \mathrm{W}_{\mathrm{t}}^{\phi \mathrm{w}(1+\chi)}$,

(19) $\mathrm{WA}_{\mathrm{t}}=\mathrm{E}_{\mathrm{t}} \sum_{\mathrm{j}=\mathrm{t}}^{\infty}(\omega \beta)^{\mathrm{j}-\mathrm{t}}\left(1-\tau_{\mathrm{w}, \mathrm{t}}\right) \lambda_{\mathrm{j}} \mathrm{N}_{\mathrm{j}} \mathrm{W}_{\mathrm{j}}^{\phi \mathrm{w}}=\omega \beta \mathrm{E}_{\mathrm{t}} \mathrm{WA}_{\mathrm{t}+1}+\left(1-\tau_{\mathrm{w}, \mathrm{t}}\right) \lambda_{\mathrm{t}} \mathrm{N}_{\mathrm{t}} \mathrm{W}_{\mathrm{t}}^{\phi \mathrm{w}}$,

where $\lambda_{j}$ is the household's marginal utility of nominal wealth (to be defined below). As $\omega \rightarrow 0$, all households get to reset their wages each period (the flexible wage case), and $\mathrm{W}_{t}^{*}(\mathrm{~h})=\mu_{\mathrm{w}} \mathrm{N}_{\mathrm{t}} \mathrm{x} / \lambda_{\mathrm{t}}$; that is, the wage is a markup over the (dollar value of the) marginal disutility of work. Since the markup is positive $\left(\mu_{\mathrm{w}}>1\right)$, the labor supplied will be inefficiently low in the flexible wage solution. Note that $1 / \chi$ is the Frisch (or constant $\lambda_{t}$ ) elasticity of labor supply.

When wages are sticky $(\omega>0)$, wage rates will generally differ across households, and firms will demand more labor from households charging lower wages. Our model is inherently one of heterogeneous agents, but complete contingent claims markets imply that all households have the same marginal utility of wealth, $\lambda$; this make households identical in terms of their consumption and investment decisions. In equilibrium, aggregate consumption is equal to household consumption, $\mathrm{C}_{\mathrm{t}}=\mathrm{C}_{\mathrm{t}}(\mathrm{h})$; the same is true of the aggregate capital stock, $\mathrm{K}_{\mathrm{t}-1}=\mathrm{K}_{\mathrm{t}-1}(\mathrm{~h})$. So, we can write the equilibrium versions of the households' first order conditions for consumption and investment in terms of aggregate values:

(20) $1 / \mathrm{P}_{\mathrm{t}} \mathrm{C}_{\mathrm{t}}=\left(1+\tau_{\mathrm{c}, \mathrm{t}}\right) \lambda_{\mathrm{t}}$,

(21) $\beta \mathrm{E}_{\mathrm{t}}\left[\lambda_{\mathrm{t}+1} / \lambda_{\mathrm{t}}\right]=\mathrm{E}_{\mathrm{t}}\left[\Delta_{\mathrm{t}, \mathrm{t}+1}\right]=\left(1+\mathrm{i}_{\mathrm{t}}\right)^{-1}$

(22) $\lambda_{t} P_{t}=\xi_{t}-\xi_{t} \psi\left[\left(I_{t} / K_{t-1}\right)-\delta\right]$,

(23) $\xi_{\mathrm{t}}=\beta \mathrm{E}_{\mathrm{t}}\left\{\lambda_{\mathrm{t}+1} \mathrm{R}_{\mathrm{t}+1}+\xi_{\mathrm{t}+1}\left[(1-\delta)-1 / 2 \psi\left[\left(\mathrm{I}_{\mathrm{t}+1} / \mathrm{K}_{\mathrm{t}}\right)-\delta\right]^{2}+\psi\left[\left(\mathrm{I}_{\mathrm{t}+1} / \mathrm{K}_{\mathrm{t}}\right)-\delta\right]\left(\mathrm{I}_{\mathrm{t}+1} / \mathrm{K}_{\mathrm{t}}\right)\right\}\right.$

where $\lambda_{\mathrm{t}}$ and $\xi_{\mathrm{t}}$ are the Lagrangian multipliers for the households' budget and capital accumulation constraints, and $i_{t}$ is the return on a 'risk free' bond. 
2.A.3. The aggregate price and wage levels, aggregate employment and aggregate output-

The aggregate price level can be written as

(24) $\mathrm{P}_{\mathrm{t}}=\left[\int_{0}^{1} \mathrm{P}_{\mathrm{t}}(\mathrm{f})^{1-\phi p} \mathrm{df}\right]^{1 /(1-\phi p)}=\left[\sum_{\mathrm{j}=0}^{\infty}(1-\alpha) \alpha^{\mathrm{j}}\left(\mathrm{P}_{\mathrm{t}-\mathrm{j}}^{*}(\mathrm{f})\right)^{1-\phi p}\right]^{1 /(1-\phi p)}$,

since the law of large numbers implies that $(1-\alpha) \alpha^{j}$ is the fraction of firms that set their prices $t-j$ periods ago, and have not gotten to reset them since. It is straightforward to show that (25) $\mathrm{P}_{\mathrm{t}}^{1-\phi p}=(1-\alpha) \mathrm{P}_{\mathrm{t}}^{* 1-\phi p}+\alpha\left(\mathrm{P}_{\mathrm{t}-1}\right)^{1-\phi p}$.

Similarly, the aggregate wage (defined by equation (12)) can be written as (26) $\mathrm{W}_{\mathrm{t}}^{1-\phi \mathrm{w}}=(1-\omega) \mathrm{W}_{\mathrm{t}}^{* 1-\phi \mathrm{w}}+\omega\left(\mathrm{W}_{\mathrm{t}-1}\right)^{1-\phi \mathrm{w}}$.

In Canzoneri, Cumby and Diba (2004), we showed that aggregate output can be written as (27) $\mathrm{Y}_{\mathrm{t}}=\mathrm{Z}_{\mathrm{t}} \mathrm{K}_{\mathrm{t}-1}{ }^{v} \mathrm{~N}_{\mathrm{t}}{ }^{1-v} / \mathrm{DP}_{\mathrm{t}}$,

where $\mathrm{N}_{\mathrm{t}}=\int_{0}^{1} \mathrm{~N}_{\mathrm{t}}(\mathrm{f}) \mathrm{df}$ is aggregate employment, $\mathrm{K}_{\mathrm{t}-1}=\int_{0}^{1} \mathrm{~K}_{\mathrm{t}-1}(\mathrm{~h}) \mathrm{dh}$ is the aggregate capital stock, and $\mathrm{DP}_{\mathrm{t}}=\int_{0}^{1}\left(\mathrm{P}_{\mathrm{t}} / \mathrm{P}_{\mathrm{t}}(\mathrm{f})\right)^{\phi \mathrm{p}} \mathrm{df}$ is a measure of the price dispersion across firms; $\mathrm{DP}_{\mathrm{t}}$ can be written as (28) $\mathrm{DP}_{\mathrm{t}}=(1-\alpha)\left(\mathrm{P}_{\mathrm{t}} / \mathrm{P}_{\mathrm{t}}^{*}(\mathrm{f})\right)^{\phi \mathrm{p}}+\alpha\left(\mathrm{P}_{\mathrm{t}} / \mathrm{P}_{\mathrm{t}-1}\right)^{\phi \mathrm{p}} \mathrm{DP} \mathrm{P}_{\mathrm{t}-1}$.

The inefficiency due to price dispersion can be seen in equation (27). Each firm has the same marginal cost (equation (3)); so, consumers should choose equal amounts of the firms' products to maximize the consumption good aggregator (4). If prices are flexible $(\alpha=0)$, then $\mathrm{P}_{\mathrm{t}}(\mathrm{f})$ $=\mathrm{P}_{\mathrm{t}}$ for all $\mathrm{f}$, and this efficiency condition will be met; if prices are sticky $(\alpha>0)$, then product prices will differ, and consumption decisions will be distorted. This distortion is manifested in equation (27). If prices are flexible, $\mathrm{DP}_{\mathrm{t}}=1$ and aggregate output is maximized for a given labor input; if prices are sticky, $\mathrm{DP}_{\mathrm{t}}>1$, and output will be less for a given labor input.

\section{A.4. Monetary and Fiscal Policy}

The ECB sets the interest rate for the Euro area in response to movements in the aggregate 
(Euro area) inflation rate:

(29) $i_{t}=-\log (\beta)+\theta \pi_{t}$,

where $\pi_{t}$ is aggregate inflation, and $\theta$ measures the strength of the ECB's response to aggregate inflation. In Section 2.B, we explain how $\pi_{\mathrm{t}}$ is related to national inflation, and in Section 4 , we will see that the Euro area's common monetary policy, (29), leads to asymmetries in the effects of a common monetary policy on national economies.

The government's flow budget constraint in period $t$ is:

$$
D_{t}=i_{t-1}\left(P_{t-1} / P_{t}\right) D_{t-1}+G_{t}+T R_{t}-\tau_{c, t} C_{t}-\tau_{w, t}\left(W_{t} / P_{t}\right) N_{t}
$$

where $\mathrm{D}_{\mathrm{t}}$ is the (end of period) real government debt, $\mathrm{i}_{\mathrm{t}-1}\left(\mathrm{P}_{\mathrm{t}-1} / \mathrm{P}_{\mathrm{t}}\right) \mathrm{D}_{\mathrm{t}-1}$ is real payment on last period's debt, $G_{t}$ is real government purchases, $T R_{t}$ is real government transfers, $\tau_{c, t} C_{t}$ is the real consumption tax revenue, and $\tau_{w, t}\left(\mathrm{~W}_{\mathrm{t}} / \mathrm{P}_{\mathrm{t}}\right) \mathrm{N}_{\mathrm{t}}$ is the real wage tax revenue. The real budget surplus is:

(31) $\mathrm{S}_{\mathrm{t}}=\tau_{\mathrm{c}, \mathrm{t}} \mathrm{C}_{\mathrm{t}}+\tau_{\mathrm{w}, \mathrm{t}}\left(\mathrm{W}_{\mathrm{t}} / \mathrm{P}_{\mathrm{t}}\right) \mathrm{N}_{\mathrm{t}}-\left[\mathrm{i}_{\mathrm{t}-1}\left(\mathrm{P}_{\mathrm{t}-1} / \mathrm{P}_{\mathrm{t}}\right) \mathrm{D}_{\mathrm{t}-1}+\mathrm{G}_{\mathrm{t}}+\mathrm{TR}_{\mathrm{t}}\right]$

In the benchmark models, the logarithm of government purchases is an auto-regressive process:

$$
\log \left(G_{t}\right)=\left(1-\rho_{g}\right) \log (\bar{G})+\rho_{g} \log \left(G_{t-1}\right)+\epsilon_{g, t}
$$

where bars over variables signify steady state values. The logarithm of government transfers respond to the level of last period's debt:

$$
\log \left(\mathrm{TR}_{\mathrm{t}}\right)=\left(1-\rho_{\mathrm{tr}}\right) \log (\overline{\mathrm{T}} \overline{\mathrm{R}})+\rho_{\mathrm{tr}} \log \left(\mathrm{TR}_{\mathrm{t}-1}\right)+\rho_{\mathrm{d}}\left[\log (\overline{\mathrm{D}})-\log \left(\mathrm{D}_{\mathrm{t}-1}\right)\right]+\epsilon_{\mathrm{tr}, \mathrm{t}}
$$

where the response of transfers to debt $-\rho_{d}$ - ensures fiscal solvency. ${ }^{7}$ In the benchmark models,

${ }^{7}$ Using Woodford's (1995) terminology, this is how we make our fiscal regime "Ricardian." Our choice to put the reaction to debt into the equation for transfers was partly motivated by our empirical results. We found no significant or systematic reaction to debt or deficit variables in our estimated equations for taxes. By contrast, we found strong and significant reactions to debt in our estimated equations for transfers and/or government purchases for most countries. We put the response in transfers (which are lump sum) to minimize the auxiliary effects on other variables. 
the tax rates also follow auto-regressive processes:

$$
\begin{aligned}
& \text { (34) } \tau_{\mathrm{c}, \mathrm{t}}=\left(1-\rho_{\tau \mathrm{c}}\right) \bar{\tau}_{\mathrm{c}}+\rho_{\tau \mathrm{c}} \tau_{\mathrm{c}, \mathrm{t}-1}+\epsilon_{\tau \mathrm{c}, \mathrm{t}} \\
& \text { (35) } \tau_{\mathrm{w}, \mathrm{t}}=\left(1-\rho_{\tau \mathrm{w}}\right) \bar{\tau}_{\mathrm{w}}+\rho_{\tau \mathrm{w}} \tau_{\mathrm{w}, \mathrm{t}-1}+\epsilon_{\tau \mathrm{w}, \mathrm{t}}
\end{aligned}
$$

In later sections, we will allow for alternative specifications of tax and spending rules.

\section{A.5. National welfare}

Our measure of national welfare is

(36) $\mathrm{U}_{\mathrm{t}}=\mathrm{E}_{\mathrm{t}} \sum_{\tau=\mathrm{t}}^{\infty} \beta^{\tau-\mathrm{t}}\left[\log \left(\mathrm{C}_{\tau}\right)-(1+\chi)^{-1} \mathrm{AL}_{\tau}\right]$

where $C_{t}\left(=\int_{0}^{1} C_{t}(h) d h=C_{t}(h)\right.$ for all $\left.h\right)$ is per capita consumption, and $A_{t}=\int_{0}^{1} L_{t}(h)^{1+\chi} d h$ is the average disutility of work. If wages are flexible $(\omega=0)$, then $\mathrm{W}_{t}(\mathrm{~h})=\mathrm{W}_{\mathrm{t}}$ for all $\mathrm{h}$, and firms hire the same hours of work from each household; $A L_{t}=\int_{0}^{1} L_{t}(h)^{1+\chi} d h=L_{t}(h)^{1+\chi} \int_{0}^{1} d h=L_{t}(h)^{1+\chi}$. In this special case, households are identical, and our measure of welfare, $\mathrm{U}_{\mathrm{t}}$, reduces to individual household utility.

If wages are sticky $(\omega>0)$, then there is a dispersion of wages that makes firms hire different hours of work from each household. This creates an inefficiency similar to the inefficiency due to price dispersion: the composite labor service used by firms $\left.-N_{t}=\int_{0}^{1} L_{t}(h)^{(\phi w-1) / \phi w} d h\right]^{\phi w /(\phi w-1)}-$ will not be maximized for a given aggregate labor input $\int_{0}^{1} \mathrm{~L}_{\mathrm{t}}(\mathrm{h}) \mathrm{dh}$. This distortion in firms' hiring decisions manifests itself in the AL term in equation (36). In Canzoneri, Cumby and Diba (2004), we showed that

(37) $\mathrm{AL}_{\mathrm{t}}=\mathrm{N}_{\mathrm{t}}^{1+\chi} \mathrm{DW}_{\mathrm{t}}$

$$
\mathrm{DW}_{\mathrm{t}}=(1-\omega)\left(\mathrm{W}_{\mathrm{t}}^{*}(\mathrm{~h}) / \mathrm{W}_{\mathrm{t}}\right)^{-\phi \mathrm{w}(1+\chi)}+\omega\left(\mathrm{W}_{\mathrm{t}-1} / \mathrm{W}_{\mathrm{t}}\right)^{-\phi \mathrm{w}(1+\chi)} \mathrm{DW}_{\mathrm{t}-1}
$$

where $\mathrm{DW}_{\mathrm{t}}=\int_{0}^{1}\left(\mathrm{~W}_{\mathrm{t}}(\mathrm{h}) / \mathrm{W}_{\mathrm{t}}\right)^{-\phi \mathrm{w}(1+\chi)} \mathrm{dh}$ is a measure of wage dispersion, analogous to $\mathrm{DP}_{\mathrm{t}}$ for prices. 
2.A.6. Making welfare comparisons with Lucas's (2004) consumption costs

Let $\mathrm{V}_{\mathrm{t}}$ be the value function for aggregate welfare in period $t$. In light of (36), $\mathrm{V}_{\mathrm{t}}$ is given by (39) $\mathrm{V}_{\mathrm{t}}=\log \left(\mathrm{C}_{\mathrm{t}}\right)-(1+\chi)^{-1} \mathrm{AL}_{\mathrm{t}}+\beta \mathrm{E}_{\mathrm{t}}\left[\mathrm{V}_{\mathrm{t}+1}\right]$

In what follows, we will calculate second order approximations of $\mathrm{V}_{\mathrm{t}}$ to make various welfare comparisons. We calculate conditional welfare, for any given parameters, by evaluating the value function at the deterministic steady state, and denote this value as $\mathrm{V}_{0}$. For example, let country $\mathrm{A}$ - with a value function denoted by $\mathrm{V}_{\mathrm{t}}(\mathrm{A})$ - be an economy with nominal inertia characterized by $(\alpha$, $\omega)=(.67, .75)$, and let country $B-$ with value function $V_{t}(B)-$ be a similar economy, but with no nominal inertia $((\alpha, \omega)=(0,0))$. Then, the difference $-V_{0}(B)-V_{0}(A)-$ can be thought of as the welfare cost of nominal inertia.

Following Lucas (2003), we can interpret $V_{0}(B)-V_{0}(A)$ as something that has comprehensible units. In Canzoneri, Cumby and Diba (2004), we showed that $V_{0}(B)-V_{0}(A)$ is the percentage of consumption households in economy A would on average be willing to give up each period, holding their work effort constant, to obtain the flexible wage/price values of consumption and work effort in economy $B . V_{0}(B)-V_{0}(A)$ is Lucas's consumption cost of nominal inertia. In a similar vein, we can make welfare comparisons between high and low debt countries, or big and small countries, in terms of consumption costs.

\section{B. Three Parameterizations of the Model}

We do not attempt a detailed calibration of any particular country; instead, we calibrate our model to represent prototypical countries in the Euro area. For reasons that will become clear, we choose three separate parameterizations for monetary and fiscal policy: one for an 'Average 
Country', a second for a 'High Debt Country', and the third for a 'Large Country'. In the first part of this section, we present data on several fiscal measures, and report on some analysis that we use to set the parameters in our fiscal policy rules. In the second part of this section, we examine data on Euro area inflation rates. The ECB sets a single monetary policy based on Euro area inflation; so, the relationship between the Euro area inflation rate and the national inflation rates plays a potentially important role in the transmission of monetary policy to individual countries.

\section{B.1. Fiscal Policy Indicators in the Euro Area Countries.}

To solve our model numerically, we need steady state values and parameters describing the dynamics and volatilities of five fiscal measures: the ratios of debt, government purchases, and government transfers to GDP, and the average tax rates on labor income and consumption. Table 1 presents averages computed over a sample of 1996-2001 for these five fiscal indicators.

The data summarized in Table 1 suggests two types of countries - a country with an average level of debt in the 60 - 70 percent of GDP range and a country with a high level of debt in the 100 120 percent of GDP range. In our numerical analysis, we assume that the Average Country's debt is 70 percent of GDP, while the High Debt Country's debt is 100 percent of GDP. (The Large Country discussed in Section 2.B.2 is considered to be a low debt country; it has the same fiscal parameters as the Average Country.)

We assume that both the Average Country and the High Debt Country have government purchases (government consumption and fixed investment) of 22 percent of GDP. We set the average tax rates on labor income and consumption to be 35 percent and 15 percent respectively for the average country.

The government's budget must be balanced in the steady state of our model. Because our 
model is missing some sources of revenue, and since the Euro area countries did not run balanced budgets during this sample, we need to set the steady state level of at least one of our fiscal variables at a value that differs from the data in Table 1. Although we have distortionary taxes in the model, we will see that government transfers do very little. We therefore chose to let transfers deviate from the data. We set them at about seven percent of GDP for our Average Country; this achieves a balanced budget in the steady state. The high debt country's budget must also be balanced in the steady state. Countries with high debt also tend to have high tax rates, so we set the average tax rates on labor income and consumption to be 40 percent and 17 percent respectively in the High Debt country; we set transfers to be 10 percent of GDP to balance the budget in the steady state.

We assume that both government spending and government transfers can be described by autoregressive processes. First we HP filter purchases and transfers (both deflated by the GDP deflator); then we estimate first order autoregressions using a sample of 1975 - 2001. For (the log of) government purchases, we find that 0.75 in annual data, which corresponds to 0.93 in quarterly data, is a representative value for the autoregressive coefficient and that 0.015 is a representative value for the volatility of the (quarterly) innovation. For (the log of) transfers, we find that 0.67 in annual data, which corresponds to 0.90 in quarterly data, is a representative value for the autoregressive coefficient and that 0.019 is a representative value for the volatility of the (quarterly) innovation.

As noted in section 2.A.4, we need to make the primary budget surplus react to the level of debt to insure that the government's present value budget constraint holds. Again, in an attempt to set our fiscal rules in a way that is consistent with the data, we add the lagged ratio of debt to GDP 
to our autoregressions for purchases and transfers. ${ }^{8}$ We find evidence that both purchases and transfers react. For each variable, the coefficient on the lagged ratio of debt to GDP is negative for ten of the eleven Euro area countries for which we have data. The coefficient in the regressions using purchases is statistically significantly negative for seven of the eleven countries and the coefficient in the regressions using transfers is significantly negative for six of the eleven. We have solved the model both ways, assuming that purchases react to debt or assuming that transfers react to debt, and we find that the results are broadly similar; we report only the latter results. We find that 0.1 is a representative value for the response of (the log of) transfers to the lagged ratio of debt to GDP, and we use that value in our numerical solutions.

Shocks to tax rates, like shocks to government purchases and transfers, are persistent, but they are much less volatile. We estimate autoregressions for the two average tax rates and find that 0.66 and 0.52 are representative values for autoregressive coefficients in the annual data (corresponding to 0.90 and 0.85 in quarterly data). The innovations have volatilities of only 0.0048 for the wage tax rate and 0.0038 for the consumption tax rate. These are less than a third of the volatilities of government purchases and transfers. We also added the lagged value of the ratio of debt to GDP to the autoregressions, as well as measures of the output gap and/or the ratio of the budget surplus (overall and primary) to GDP, but we found no systematic evidence that the average tax rates react to any of these variables. The signs of the coefficients were mixed and very few were statistically significant. ${ }^{9}$

${ }^{8}$ As we discuss below, we do not find systematic evidence that either the average tax rate on labor income or consumption reacts to the lagged ratio of debt to GDP.

${ }^{9}$ We estimated both least squares regressions with lagged values and instrumental variables regressions with contemporaneous values. 


\section{B.2 National and Euro Area Inflation}

As discussed in section 2.A.4, we assume that the ECB implements monetary policy by setting the interest rate in response to Euro area wide inflation. Shocks that cause inflation in any single country will induce a response by the ECB only to the extent that the country's inflation is correlated with Euro area wide inflation. Similarly, movements in Euro area wide inflation that are unrelated to the inflation rate in an individual country will result in a reaction by the $\mathrm{ECB}$, and the resulting movement in interest rates will be a monetary policy shock to that country. ${ }^{10}$

To summarize the relationship between the Euro area inflation rate and country specific inflation rates, we regress aggregate inflation on national inflation:

(39) $\pi_{\mathrm{t}}=\theta_{\mathrm{c}} \pi_{\mathrm{c}, \mathrm{t}}+\epsilon_{\pi \mathrm{c}, \mathrm{t}}$

where $\pi_{\mathrm{c}, \mathrm{t}}$ is inflation in country $\mathrm{c}$ and $\epsilon_{\pi \mathrm{c}, \mathrm{t}}$ is the component of Euro area inflation that is orthogonal to country c's inflation. The results, which we report in Table 2, show a wide range of slope coefficients. It is perhaps not surprising that the inflation rates of France and Germany are more closely related to Euro area wide inflation than are the inflation rates of the other countries - the slope coefficients are larger and the volatilities of the innovations are smaller. Those two countries are, after all, the largest in the Euro area. Because of this difference, we will look at an average (small) country and a hypothetical large country when we solve our model numerically. We will set $\theta_{\mathrm{c}}$ to 0.4 and $\sigma_{\pi \mathrm{c}}$ to 0.0028 for the Average Country, and we will set $\theta_{\mathrm{c}}$ to 0.75 and $\sigma_{\pi \mathrm{c}}$ to 0.002 for the Large Country.

${ }^{10}$ Thus countries in the Euro area will be subject to monetary policy shocks even when the interest rate rule itself contains no shock (as we have assumed here). 


\section{An Overview of the Model and the Role Played by Productivity}

In this section, we provide an overview of the model, focusing on the role played by productivity shocks. In the following sections, we discuss the ways in which monetary and fiscal policy impinge on each other.

We used Dynare (see Juillard (2003)) to solve the model numerically. We used first order approximations to calculate the moments and variance decompositions reported in Tables 3, 4 and 5, and to plot the impulse response functions shown in Figures 1, 2 and 3. The model is calibrated to a quarterly frequency; variables are expressed as logarithms (except for interest rates); and all of the data have been HP filtered. We used second order approximations of the value function, (32), to calculate welfare: $\mathrm{C}$ is the cost of nominal inertia, expressed as the percent of consumption an average household would be willing to give up each period to obtain the flexible wage/price solutions for consumption and work effort.

The results of the numerical solutions of the model are reported in Tables 3, 4, and 5. These results are similar to those of the model considered in Canzoneri, Cumby, and Diba (2004a), which captures several important features of the data remarkably well. In particular, that model generates volatilities of consumption, investment, output, employment, and real wages that are very close to those found in the U.S. data. In addition, it generates the kind of volatility that has been observed in the efficiency gaps emphasized by Erceg, Henderson and Levin (2000) and Gali, Gertler and Lopez-Salido (2002). And like that model, our current model fails to match the data in some potentially important ways. For example, Tables 3, 4 and 5 show that inflation and output are negatively correlated in all three parameterizations of the model, whereas in Canzoneri, Cumby, and Diba (2004a) we show that inflation and output are positively correlated in the actual data. 
Similarly, nominal interest rates and output are negatively correlated in the models, but positively correlated in the data. These facts suggest the absence - or improper modeling - of traditional demand side shocks. ${ }^{11}$ In older Keynesian models, an increase in aggregate demand (or shift of the IS curve) raises output and leads to inflationary pressures, causing the central bank to increase the interest rate. Such a demand shock would bring our model closer to matching the positive correlations of output with inflation and the interest rate observed in the data.

The variance decompositions in Tables 3, 4 and 5 tend to confirm these suspicions. The productivity shock, $\epsilon_{\mathrm{p}}$, explains ninety percent of the variation in inflation, and over half of the variation in output. It is easy to see (mechanically anyway) why productivity shocks play such an important role in the volatility of inflation. Equation (8) implies that new prices are driven by marginal cost, and equation (3) shows that marginal cost can be written in terms of factor prices $\mathrm{R}$ and $\mathrm{W}-$ and productivity $-\mathrm{Z}$. Wages are inertia ridden, and the rental rate on capital plays a minor role since capital's share is small; so, productivity shocks play the major role in driving marginal cost and inflation. ${ }^{12}$ In fact, we suspect productivity shocks play a disproportionate role in these models - a theme that we will come back to repeatedly.

The impulse response functions in Figures 1A, 2A, and 3A show how a typical productivity shock propagates through the three versions of the model. Beginning with the Average Country, a positive productivity shock decreases marginal cost, causing new prices to fall. As national inflation rates are positively correlated in the Euro area, the fall in national inflation is associated

${ }^{11}$ The strong negative correlation between interest rates and output remains when set $\alpha=$ $\omega=0$, eliminating the nominal rigidities and therefore the effect of the demand shocks.

${ }^{12}$ In the Average Country Model, the correlation between inflation and (real) marginal cost is 0.98 , and productivity shocks explain $88 \%$ of the variation in (real) marginal cost. 
with a decrease in Euro area inflation, and the ECB decreases the interest rate. This causes consumption and investment to rise, increasing output and employment. Turning to the fiscal variables: lower interest rates decrease interest payments on the debt (interest/GDP in the figures); higher levels of consumption and employment increase the consumption and wage tax revenues (cons tax rev/GDP and wage tax rev/GDP); total tax revenues (total rev/GDP) - rise. All of these factors combine to lower the deficit (deficit/GDP in the figures).

Turning to the High Debt Country, the basic story is much the same. However, the fall in the interest rate has a bigger effect on interest/GDP than in the Average Country, and deficit/GDP falls more. In the Large Country, the ECB's monetary policy limits the fall in inflation (for reasons discussed in Section III); so, the real interest rate falls more than in the Average Country, and consumption, investment and output rise more.

Productivity shocks play a very important role in the volatility of the deficit to GDP ratio. From Tables3, 4 and 5, productivity shocks explain about $40 \%$ of the variation in deficit/GDP in the Average Country, $40 \%$ in the High Debt Country, and $60 \%$ in the Large Country. ${ }^{13}$ Rules like the SGP try to discipline fiscal decision making by forcing fiscal policy to limit the unconditional volatility of the deficit-to-GDP ratio. But, in this context, it seems perverse to make fiscal policy offset the volatility in fiscal balances that is created by productivity shocks; this volatility has nothing to do with a lack of fiscal discipline. This is another theme we will come back to.

Tables 3, 4 and 5 also report some welfare results. $V_{0}$ represents the expected value of national welfare, conditional on state variables being initially at their non-stochastic steady-state

\footnotetext{
${ }^{13}$ Productivity shocks move interest rates more in the Large Country Model since the response of Euro area inflation to movements in national inflation is greater. This effect will be discussed in more detail in Section 5.
} 
values. $\mathrm{V}_{0}$ is equal to - 18.2 for the Average Country, -19.5 for the High Debt Country, and - 16.7 for the Large Debt Country. As explained in Section 2.A.5, these welfare differences can be interpreted as consumption equivalents: the typical household in the Average Country would be willing to give up $1.5 \%$ (= $18.2-16.7)$ of consumption each period to live in the Large Country, and the typical household in the Average Country would have to be given $1.3 \%(=19.5-18.2)$ more consumption each period to make it move to the High Debt Country. The tables also report the consumption costs of nominal inertia in the three countries: $1.9 \%$ in both the Average Country and the High Debt Country, and only $0.4 \%$ in the Large Country.

It is easy to understand why welfare is lower in the high debt country; it needs high distortionary tax rates to service its debt. The reason why welfare is higher in the big country is less obvious: the ECB's interest rate is more sensitive to movements in its inflation rate; we will discuss this further in Section 4.

\section{How Monetary Policy Impinges on National Fiscal Policy and National Welfare}

The ECB sets the interest rate for the entire Euro area, based upon movements in aggregate (Euro area) inflation. Since national inflation rates are not perfectly correlated with the aggregate inflation rate, the ECB's policy is not symmetric across countries. In this section, we show where the asymmetries come from, and how the ECB's policy affects national fiscal policy and national welfare in small countries, in large countries, and in high debt countries.

The asymmetries in monetary policy work through two channels, both of which derive from our projections of aggregate Euro area inflation on national inflation (reported in Section 2.B). The ECB sets the interest rate in response to movements in aggregate inflation: 
(40) $\mathrm{i}_{\mathrm{t}}=-\log (\beta)+\theta \pi_{\mathrm{t}}$,

where $\pi_{t}$ is aggregate inflation. Our regressions project aggregate inflation on national inflation: (41) $\pi_{\mathrm{t}}=\theta_{\mathrm{c}} \pi_{\mathrm{c}, \mathrm{t}}+\epsilon_{\pi \mathrm{c}, \mathrm{t}}$

where $\pi_{\mathrm{c}, \mathrm{t}}$ is inflation in country c. Substituting (41) into (40), the ECB's policy can be expressed in terms of inflation in country $\mathrm{c}$ and an interest rate shock:

(42) $\mathrm{i}_{\mathrm{t}}=-\log (\beta)+\left(\theta \theta_{\mathrm{c}}\right) \pi_{\mathrm{c}, \mathrm{t}}+\epsilon_{\mathrm{ic}, \mathrm{t}}$

where $\epsilon_{\mathrm{ic}, \mathrm{t}}=\theta \epsilon_{\pi \mathrm{c}, \mathrm{t}}$.

The first asymmetry in monetary policy is that the ECB does not respond to national inflation in the same way for each country. Our regressions show that $\theta_{c}$ is much bigger in large countries than it is in small countries. In our models, we set the ECB's $\theta$ equal 2.7. ${ }^{14}$ In the Large Country Model, we set $\theta_{c}$ equal to 0.75 . The Average Country and the High Debt Country are assumed to be small countries, and we set $\theta_{c}$ equal to 0.4 in those models. So, the ECB's response to inflation in the Large Country Model is $\theta \theta_{c}=2.025$, while its response to inflation in the other two models is only $\theta \theta_{\mathrm{c}}=1.08$.

The second asymmetry in monetary policy is that the size of the interest rate shock differs across countries. Our regressions show that the standard deviation of $\epsilon_{\pi \mathrm{c}, \mathrm{t}}$ is much smaller in the large countries than it is in the small countries. We let the variance of $\epsilon_{\pi \mathrm{c}, \mathrm{t}}$ in the Large Country Model be half the size it takes in the other two models. Note that the ECB's choice of $\theta$ scales this shock up to what we call the interest rate shock, $\epsilon_{\mathrm{i}, \mathrm{t}}$. The greater is the ECB's reaction to Euro area

${ }^{14}$ This value is based on estimates of a "traditional Taylor rule" in Gerlach-Kristen (2003). Other estimates of the response to inflation in Gerlach-Kristen (2003) and Surico (2003) are below unity. These values would raise determinacy issues in our model that we do not address here. 
inflation, the larger is the interest rate shock. This effect is especially large for countries with large idiosyncratic inflation variance.

The two asymmetries help explain some of the welfare differences reported at the end of Section 3. The typical household in the Average Country and in the High Debt Country would be willing to give up $1.9 \%$ of consumption each period to be rid of wage and price inertia; households in the Large Country would only give up $0.4 \%$. Part of the difference is due to the fact that interest rate shocks are smaller in the Large Country, and part is due to the fact that the ECB responds more aggressively to inflation in the Large Country: in Canzoneri, Cumby and Diba (2004b), we showed that increasing the response of interest rates to inflation will - up to a point - decrease the consumption cost of nominal inertia. ${ }^{15}$

The impulse response functions in Figures 1B, 2B, and 3B show how a typical interest rate shock propagates through the three versions of the model. Beginning with the Average Country, the higher nominal interest rate lowers inflation, and the real interest rate rises. Consumption, investment and output fall, and employment falls. This decreases revenue from both the consumption tax and the labor tax, and the higher interest rate means higher interest payments on the debt. All of these factors combine to raise the deficit-to-GDP ratio.

Turning to the High Debt Country, the basic story is once again much the same. However, the fall in the interest rate has a bigger effect on interest/GDP than in the Average Country, and

${ }^{15}$ King and Wolman (1999) showed that fixing the price level achieved the constrained optimum in an NNS model characterized by price inertia, but Erceg, Henderson and Levin (2000) that an inflation - output tradeoff arises when wage inertia is added. In Canzoneri, Cumby and Diba (2004), we used variants of the Erceg, Henderson and Levin model to show that there is an optimal value for $\theta$ in a rule like (33); lowering the volatility of inflation beyond a certain point is welfare decreasing. 
deficit/GDP falls more. In the Large Country, the size of a typical interest rate shock is smaller; this alone diminishes the importance of the shocks. However, the Large Country also benefits from the fact that ECB policy responds more vigorously to changes in its inflation rate. It limits the fall in inflation; so, the real interest rate rises less than in the Average Country, and consumption, investment and output fall less. Tax revenues fall less, and deficit/GDP does not rise as much.

Interest rate shocks play a very important role in the volatility of the deficit to GDP ratio, almost as important a role as productivity shocks, as can be seen in the variance decompositions reported in Tables 3, 4 and 5. As noted earlier, rules like the SGP try to discipline fiscal decision making by forcing fiscal policy to limit the unconditional volatility of the deficit to GDP ratio. But, in this context, it seems perverse to make fiscal policy offset the volatility in fiscal balances that is created by monetary policy; this volatility has nothing to do with a lack of fiscal discipline.

Put another way, all of the fiscal shocks combined - the shocks to government purchases $\left(\epsilon_{\mathrm{g}}\right)$, government transfers $\left(\epsilon_{\mathrm{tr}}\right)$, consumption tax rates $\left(\epsilon_{\tau \mathrm{c}}\right)$, and wage tax rates $\left(\epsilon_{\mathrm{tw}}\right)$ - explain less than a third of the variation in the deficit/GDP in any of the models. In the High Debt Country -

presumably the country to worry about - fiscal shocks only explain $20 \%$ of the volatility in deficit/GDP. If all of the fiscal shocks were eliminated, $80 \%$ of the volatility of deficit/GDP would remain. We turn to the implications of this for deficit constraints in the next section.

\section{How Deficit Constraints Impinge on National Inflation and Welfare}

In Section 4, we discussed direct ways in which the ECB's monetary policy affects national fiscal policy and welfare. In this section, we discuss an indirect way in which the monetary policy may impinge on fiscal policy and welfare in the Euro area. In particular, it has been argued that 
constraints on deficits are necessary for price stability in a monetary union. Our results in Section 6 below do not provide a rationale for this notion, and Canzoneri and Diba's (1999) survey of the economic literature also found little support for it. Nevertheless, it is widely believed that something like the constraints embodied in the SGP are desirable. ${ }^{16}$

In this section, we compare fiscal policy rules in which either spending or tax rates respond to movements in the budget deficit. Although the questions we raise are motivated by the SGP, we do not explicitly consider a deficit ceiling of three percent of GDP. Instead, we consider rules for fiscal policy that reduce the volatility of the deficit (relative to GDP) by adjusting tax rates or spending in response to movements in deficit/GDP; this lowers the probability of hitting any particular ceiling. In part this choice is motivated by the fact that, in the steady state of our model, output does not grow and inflation is zero; so, a three percent ceiling would be quite different in our model than in the economies of the Euro area. ${ }^{17}$ And in part, this is a pragmatic choice dictated by our inability to solve the model subject to inequality constraints.

We consider rules in which either the tax rate on labor income or government purchases adjusts in response to anticipated budget deficits. ${ }^{18} \mathrm{We}$ assume that the legislative process is too sluggish for the fiscal authorities to react to deficit/GDP within the quarter, and that they determine purchases and tax rates one period in advance. The wage tax rate is now given by:

\footnotetext{
${ }^{16}$ Some would argue that fiscal discipline is needed for reasons that are not directly related to monetary policy.

${ }^{17}$ One implication of having no steady-state output growth and inflation is that the budget needs to be balanced in the steady state. This makes it exceedingly difficult to relate any particular deficit to GDP ceiling in our model to the three percent ceiling in the SGP.

${ }^{18}$ We focus on the labor tax and government purchases because there appears to be less movement in the average tax rate on consumption among the Euro area countries, and because transfers have no significant effect in our model despite the introduction of distortionary taxes.
} 
(43) $\tau_{\mathrm{w}, \mathrm{t}}=\bar{\tau}_{\mathrm{w}}-\varsigma_{\mathrm{w}} \mathrm{E}_{\mathrm{t}-1}\left(\mathrm{~S}_{\mathrm{t}} / \mathrm{Y}_{\mathrm{t}}\right)+\epsilon_{\tau \mathrm{w}, \mathrm{t}}$,

and government purchases are given by:

(44) $\log \left(\mathrm{G}_{\mathrm{t}}\right)=\left(1-\rho_{\mathrm{g}}\right) \log (\overline{\mathrm{G}})+\rho_{\mathrm{g}} \log \left(\mathrm{G}_{\mathrm{t}-1}\right)+\varsigma_{\mathrm{g}} \mathrm{E}_{\mathrm{t}-1}\left(\mathrm{~S}_{\mathrm{t}} / \mathrm{Y}_{\mathrm{t}}\right)+\epsilon_{\mathrm{g}, \mathrm{t}}$

As in the previous sections, we set the steady state value of $\bar{\tau}_{w}$ to 0.40 and set $\bar{G}$ so that the steady state ratio of government purchases to output is 0.22 with $\rho_{\mathrm{g}}=0.93$.

In what follows, we use either $\varsigma_{\mathrm{w}}$ or $\varsigma_{\mathrm{g}}$ to reduce the standard deviation of deficit/GDP from 0.0146 to 0.01 . Under either of these policies, the probability that the deficit will exceed two percent of GDP falls from more than 17 percent to less than 5 percent. Table 6 summarizes the impact of these fiscal rules on the High Debt Country. ${ }^{19}$ The effects of either rule can be best understood by considering how the economy responds to the shocks to productivity and the interest rate, since they are the dominant sources of fluctuations in our models.

Consider the case in which the wage tax rule is used to stabilize deficit/GDP; as before, $\varsigma_{\mathrm{g}}$ is set equal to zero. A negative productivity shock will reduce output and consumption, although by less than would be the case if wages and prices were flexible. Labor income also falls along with consumption, so that tax revenues decline and deficit/GDP rises. If the wage tax rate rises in response, consumption and output fall by more. ${ }^{20}$ Consequently, output and consumption volatility increase. Inflation volatility rises only slightly.

A positive interest rate shock will also reduce consumption, output, and labor income. The resulting increase in deficit/GDP will induce an increase in the wage tax rate, bringing about a

${ }^{19}$ Implications for the Average Country are similar, but some of the magnitudes differ.

${ }^{20}$ The responses to tax and spending shocks are pictured in Figures 1, 2 and 3, and will be discussed in more detail in Section 6. 
further decline in consumption and employment. This will increase the volatility of both consumption and employment.

If instead the government purchases rule is used to stabilize deficit/GDP (and $\varsigma_{\mathrm{w}}$ is reset at zero), the volatilities of output and employment increase, but consumption and inflation volatility fall. Following a negative productivity shock or a positive interest rate shock, the decline in purchases causes output and employment to fall by more than they did with the wage tax rule. The decline in purchases crowds in consumption, however, and consumption falls by less. Consumption volatility is considerably lower when the government purchases rule is used to stabilize deficit/GDP.

The economy is subject to distortions from the consumption and wage taxes, from market power on the part of firms and workers, and from the nominal rigidities. As a result, interpreting welfare effects is not straightforward. The interaction of our tax and spending rules with these distortions may play a role in determining the effects on welfare.

Welfare falls by about a half a percent of consumption when the wage tax rule is used to stabilize deficit/GDP. On the one hand, this is not surprising - inducing greater volatility in tax rates is generally thought to reduce welfare (Barro (1979)). On the other hand, following a negative productivity shock, nominal rigidities keep consumption from falling as much as it would with flexible wages and prices. The response of the wage tax rate reduces consumption further, and this might be thought to offset some of the effects of the nominal rigidities. This is an example of the interaction between distortions in our model that might complicate the welfare effects. It turns out however that, following a negative productivity shock, the rise in the wage tax rate makes consumption fall even more than it would with flexible wages and prices, and consumption is farther away from its flexible wage/price value. The response does not, in fact, mitigate the distortions 
arising from sticky wages and prices.

In contrast, welfare rises by about a half a percent of consumption when government purchases are used to stabilize deficit/GDP. This welfare effect is consistent with the intuition derived from a model with flexible wages and prices. By crowding in consumption, following a negative productivity shock or a positive interest rate shock, and by crowding out consumption following a positive productivity shock or a negative interest rate shock, the response of government purchases to deficit/GDP greatly reduces the volatility of consumption, thereby providing a kind of insurance to consumers. The steady state values of consumption and government purchases are, of course, unaffected by the response. But by reducing consumption when it is above its steady state value when the marginal utility of consumption is low - and raising it when the consumption is below its steady state value - when the marginal utility of consumption is high - rule for government purchases actually raises welfare.

Our finding that deficit constraints can be welfare enhancing - when done properly, with a rule for government purchases - will undoubtably be controversial. And indeed, we think that the result should be viewed with caution, for at least two reasons. First, government purchases are purely wasteful in our models. They do not enter utility functions, and they play no role in the production technology. If government purchases were to be given a more meaningful role in our models, then making them fluctuate with deficit/GDP would probably incur a welfare cost. Second, the welfare gains described above come - at least in part - from the fact that an increase in government purchases crowds out consumption in our models. The empirical literature, although 
far from unanimous, suggests that the response of consumption to a shock to purchases is positive. ${ }^{21}$ If instead, an increase in purchases lead to in an increase in consumption, then requiring purchases that respond to deficit/GDP would reduce consumption when it is low and raise consumption when it is high, adding to the volatility of consumption and reducing welfare.

\section{Does Fiscal Policy Impinge on the ECB's Ability to Control National Inflation?}

The ECB's primary concern is with stability of the aggregate (Euro area) inflation rate, and it seems to be doing well in that regard. However, the diversity of national inflation rates has been rather surprising, and as we have seen, the consequent diversity of real interest rates can affect macroeconomic stability at the national level. Can the diversity of national inflation rates be attributed to the diversity of national fiscal policies? If so, there might be an argument in favor of coordinating fiscal policies through the kind of deficit constraints that are embodied in the SGP.

Duarte and Wolman (2002) provided a tentative answer to this question. They developed an NNS model with two symmetric countries, and with stochastic processes for productivity and government purchases. They calibrated their model to German data, and solved it with and without the government spending shocks. They found that the productivity shocks alone were sufficient to explain the standard deviation of the inflation differential that has been observed for France and Germany; moreover, they found that adding the government spending shocks hardly changed the standard deviation. The diversity of national fiscal policies did not appear to impinge on monetary

${ }^{21}$ In particular, VARs reported by Fatas and Mihov (2000, 2001), Blanchard and Perotti (2002) and Canzoneri, Cumby and Diba (2002) find a positive response in U.S. data. Perotti (2004) finds mixed results and weaker evidence of a positive response after 1980 for the five countries he considers. 
policy's ability - or lack thereof - to control national inflation rates.

Our model has features that Duarte and Wolman's model does not: it has a consumption tax, in addition to the labor tax; it has shocks to the processes for tax rates and government transfers, in addition to shocks for government purchases; more generally, it has wage inertia, in addition to price inertia; they have capital; and it allows for asymmetries due to country size and the level of the debt. In this sense, our model is richer than Duarte and Wolman's; ${ }^{22}$ on the other hand, Duarte and Wolman's model has the advantage of being a general equilibrium model, while ours is partial equilibrium. In any case, the additional features in our model may imply that instability in tax and spending policies have a greater impact on national inflation rates.

However, our results confirm Duarte and Wolman's. This can be seen in the variance decompositions (Tables 3, 4 and 5): all of the fiscal shocks combined - the shocks to government purchases $\left(\epsilon_{\mathrm{g}}\right)$, government transfers $\left(\epsilon_{\mathrm{tr}}\right)$, consumption tax rates $\left(\epsilon_{\tau \mathrm{c}}\right)$, and wage tax rates $\left(\epsilon_{\tau \mathrm{w}}\right)-$ explain well less than ten percent of the variation in inflation in any of the models. It is largest for the Average Country: 7.4\%. For the High Debt and Large Countries, it is far less: $2.6 \%$ and 1.9\%, respectively.

By contrast, productivity shocks explain $90 \%$ of the variation in inflation in all three versions of our model. One of the reasons for this was already discussed in Section 3: new prices (of firms lucky enough to be able to reset them) depend upon marginal cost, and productivity feeds directly into marginal cost. We also noted that inflation and output are negatively correlated in the model, but positively correlated in the actual data. This suggests the absence of - or the lack of importance

${ }^{22}$ In addition, in the next section we will introduce some "rule of thumb" consumers in order to amplify the effects of fiscal shocks. 
of - traditional demand side shocks.

One possibility is that the tax and spending processes we have modeled are propagating in a different way in the model than they are in the actual data. In the rest of this section, we investigate the way in which our tax and spending shocks affect aggregate demand and inflation. We do this using the remaining impulse response functions pictured in Figures 1, 2 and 3.

We begin with the shock to government purchases (and Figures $1 \mathrm{C}, 2 \mathrm{C}$ and $3 \mathrm{C}$ ). In the Average Country, an increase in government purchases increases both GDP and inflation. As such, shocks to government purchases are a potential source of the positive correlation between output and inflation observed in the data. But, the shock does not affect the components of aggregate demand in ways that might be expected. What is expected? In traditional Keynesian models, and in VARs reported by Fatas and Mihov (2000, 2001), Blanchard and Perotti (2002) and Canzoneri, Cumby and Diba (2002), an increase in government purchases boosts private consumption spending and crowds out investment. In our Average Country, a government purchases shock boosts investment (at least initially) and crowds out consumption.

The rather perverse effect on investment seems to come from monetary policy. As explained in Section 4, the ECB's response to national inflation is weak in small countries, and it allows the real interest rate to fall in response to government purchases shock. In the Large Country, where the ECB's response to national inflation is strong, both consumption and investment are crowded out.

The perverse effect on consumption illustrates the Ricardian tendencies that remain in these models. Households work more, and consume less, in response to an increase in government purchases, as in the RBC models that preceded the NNS paradigm. Transfer payments have no 
effect on consumption at all. Adding nominal inertia or distortionary taxation does not change these facts. In the next section, we try to break up these remaining Ricardian influences by adding 'rule of thumb' consumers.

The effects of an increase in government purchases on the fiscal variables are perhaps what one might expect. The higher interest rate increases interest/GDP; the higher employment increases wage tax/GDP, but the lower consumption spending decreases cons tax/GDP, and total rev/GDP falls; the net effect is an increase in deficit/GDP. All three countries show the same effects.

Moving to the shock to the consumption tax rate (and Figures 1D, 2D and 3D), results are once again what one might expect. In the Average Country, a tax increase lowers consumption and output, and also inflation. Like the shock to government purchases, a consumption tax shock produces a positive correlation between inflation and output. The ECB responds to the lower inflation by cutting the interest rate; this decreases interest/GDP and causes investment to fall. Employment falls, curtailing revenue from the wage tax. However, this is outweighed by increase in consumption tax revenue and the decrease in interest payments, and deficit/GDP falls. In the High Debt Country, the story is much the same. In the Large Country, the ECB responds more vigorously to the fall in inflation. Consequently, interest/GDP rises more, and deficit/GDP falls more.

Moving finally to the shock to the wage tax (and Figures 1E, 2E and 3E), results may be a little more surprising. In the Average Country, a tax hike decreases work effort and output, and increases inflation. A wage tax increase is a supply side shock - like the productivity shock - which results in a negative correlation between inflation and output. The ECB responds to the higher inflation by raising the interest rate; this increases interest/GDP and causes investment to fall. The 
increase in wage tax revenue exceeds the decrease in consumption tax revenue, and deficit/GDP falls, despite the increase in interest payments. The story is largely the same in the other two countries.

\section{Adding Rule of Thumb Consumers}

Our NNS model with optimizing (forward-looking) households suggests a very limited role for fiscal shocks. A number of recent contributions, however, point out that models with forwardlooking households may not yield empirically plausible implications about the effects of fiscal shocks. In particular, our NNS model shares an implication of the RBC model highlighted in Fatas and Mihov (2001): in both models, an increase in government purchases has a crowding out effect on consumption. By contrast, as we note above, the empirical literature on the effects of fiscal shocks (although far from being unanimous) suggests that the response of consumption to a shock to government purchases is positive.

In this section, following Galì López-Salido and Vallés (2003a), we extend our model by introducing some households who have no assets and simply consume their current disposable income. The introduction of such households raises rather awkward theoretical questions and modeling choices that we do not address in this paper. ${ }^{23}$ In addition, our extended model only addresses one particular aspect (the response of consumption to a shock to purchases) of the

${ }^{23}$ We can neither specify an objective function for households who follow a rule of thumb, nor articulate the features of the economic environment that lead to their postulated behavior. A minimal attempt to make progress on these issues might involve following Gali López-Salido and Vallés (2003b) in modeling some myopic households who maximize their period utility. Unfortunately, besides raising the potential indeterminacy issues highlighted by Galì López-Salido and Vallés (2003b), such an approach would fail to address the empirical challenges discussed in Fatas and Mihov (2001)-- who trace the challenges to the intratemporal labor-leisure decision of optimizing households, rather than any intertemporal considerations. 
challenges posed by the empirical literature. ${ }^{24}$ Nonetheless, the basic idea that some households follow a rule of thumb seems to be viewed as a practical device in helping New Keynesian models come closer to matching the data. ${ }^{25}$

\subsection{The Extended Model and Its Parameters -}

We assume that optimizing (O) households have unit mass and behave as described in Section 2 above. We need not change the equations pertaining to these households, except for adding the subscript $\mathrm{O}$ to the relevant variables. We also envision a group of low-income, liquidityconstrained (L) households who have no assets and always consume their current disposable income. For simplicity, we give these households unit mass as well, but assume they are homogeneous and less productive than optimizing households. Specifically, the effective labor input $\mathrm{N}_{\mathrm{t}}$ entering the production function (1) above is

$$
\mathrm{N}_{\mathrm{t}}=\left[\zeta \mathrm{N}_{\mathrm{O}, \mathrm{t}}{ }^{(\eta-1) / \eta}+(1-\zeta) \mathrm{N}_{\mathrm{L}, \mathrm{t}}{ }^{(\eta-1) / \eta}\right]^{\eta /(\eta-1)}, \quad \eta>0, \quad 0.5<\zeta<1
$$

where $\mathrm{N}_{\mathrm{O}, \mathrm{t}}$ is the bundled labor input of $\mathrm{O}$ households (the CES aggregate of their differentiated labor inputs, defined in Section 2), $\mathrm{N}_{\mathrm{L}, \mathrm{t}}$ is the labor input of $\mathrm{L}$ households, and $\zeta$ determines the relative productivities of the two types of labor.

To minimize costs, firms relate their demand for the two types of labor to the CES wage index of $\mathrm{O}$ households $\left(\mathrm{W}_{\mathrm{O}, \mathrm{t}}\right)$ and to the wages of $\mathrm{L}$ households $\left(\mathrm{W}_{\mathrm{L}, \mathrm{t}}\right)$ :

$$
\left[\mathrm{N}_{\mathrm{L}, \mathrm{t}} / \mathrm{N}_{\mathrm{O}, \mathrm{t}}\right]^{1 / \eta}=\left(\mathrm{W}_{\mathrm{O}, \mathrm{t}} / \mathrm{W}_{\mathrm{L}, \mathrm{t}}\right)[(1-\zeta) / \zeta]
$$

The CES wage index for the effective labor input $\mathrm{N}_{\mathrm{t}}$ is:

${ }^{24}$ In particular, our model does not address the issue, highlighted in Fatas and Mihov (2001), of how real wages respond to a shock to government purchases.

${ }^{25}$ [Need a reference to Erceg et al. Their 2003 paper says do not quote] 
(47) $\mathrm{W}_{\mathrm{t}}=\left[\zeta^{\eta} \mathrm{W}_{\mathrm{O}, \mathrm{t}}{ }^{1-\eta}+(1-\zeta)^{\eta} \mathrm{W}_{\mathrm{L}, \mathrm{t}}{ }^{1-\eta}\right]^{1 /(1-\eta)}$

Given the new definitions of $\mathrm{N}_{\mathrm{t}}$ and $\mathrm{W}_{\mathrm{t}}$ in (45) and (47), the other equations describing the behavior of firms (marginal cost, etc.) are the same as the ones described in Section 2.

We assume (arbitrarily) that the wages of L households are proportional to the aggregate wage of O households. ${ }^{26}$ Specifically, we set

$$
\mathrm{W}_{\mathrm{L}, \mathrm{t}} / \mathrm{W}_{\mathrm{O}, \mathrm{t}}=(1-\zeta) / \zeta
$$

This implies that hours in (46) equalize across the two types, and coincide with aggregate hours. Moreover, given (48), the elasticity of substitution $\eta$ does not matter for the results we report below (we set $\eta=0.5$ in our numerical solutions of the model). We set $\zeta=0.6$ to make $W_{L, t}=(2 / 3) W_{O, t}$. Since L households have no income from capital and receive no dividends, their consumption share is lower than their share in labor income.

We assume L households receive a lump sum transfer from the government that we set to ten percent of GDP. This raises their consumption to just under 60 percent of the consumption of O households. We assume that $\mathrm{L}$ households consume their entire disposable income including the transfers $\left(\mathrm{TR}_{\mathrm{t}}\right)$ each period:

$$
\left(1+\tau_{c, t}\right) C_{L, t}=\left(1-\tau_{w, t}\right)\left(W_{L, t} / P_{t}\right) N_{L, t}+T_{t}
$$

Since both groups of households have unit mass, aggregate consumption $\left(\mathrm{C}_{t}\right)$ is

$$
\mathrm{C}_{\mathrm{t}}=\mathrm{C}_{\mathrm{O}, \mathrm{t}}+\mathrm{C}_{\mathrm{L}, \mathrm{t}}
$$

and, with the new definition of $\mathrm{C}_{t}$, the goods market clearing condition in Section 2 still applies.

The stock of real government debt $\left(\mathrm{D}_{t}\right)$ now evolves according to the budget constraint

${ }^{26}$ Galì López-Salido and Vallés (2003a) and Erceg et al. also rely on ad hoc specifications of how wages are determined. 


$$
D_{t}=\left(1+i_{t-1}\right) D_{t-1} / \pi_{c, t}+G_{t}+T R_{t}-\tau_{c, t} C_{t}-\tau_{w, t}\left(W_{O, t} N_{O, t}+W_{L, t} N_{L, t}\right) / P_{t}-\tau_{O, t}
$$

where $\tau_{\mathrm{O}, \mathrm{t}}$ is a lump sum tax levied on $\mathrm{O}$ households. The budget surplus (inclusive of interest payments) is

(52) $\mathrm{S}_{\mathrm{t}}=\tau_{\mathrm{c}, \mathrm{t}} \mathrm{C}_{\mathrm{t}}+\tau_{\mathrm{w}, \mathrm{t}}\left(\mathrm{W}_{\mathrm{O}, \mathrm{t}} \mathrm{N}_{\mathrm{O}, \mathrm{t}}+\mathrm{W}_{\mathrm{L}, \mathrm{t}} \mathrm{N}_{\mathrm{L}, \mathrm{t}}\right) / \mathrm{P}_{\mathrm{t}}+\tau_{\mathrm{O}, \mathrm{t}}-\mathrm{i}_{\mathrm{t}-1} \mathrm{D}_{\mathrm{t}-1} / \pi_{\mathrm{c}, \mathrm{t}}-\mathrm{G}_{\mathrm{t}}-\mathrm{TR}_{\mathrm{t}}$

A reasonable figure for total transfer payments in our benchmark economy would be about 18 percent of GDP, but some transfers (business subsidies, pensions, etc.) do not seem to correspond to the transfers from $\mathrm{O}$ households to $\mathrm{L}$ households in our model. We assume that the relevant transfers in our benchmark country are 10 percent of GDP. We retain our earlier assumptions about the benchmark country's consumption tax (15\%), wage tax $(35 \%)$, share of government purchases in GDP (22\%) and debt-to-GDP ratio (70\%). We have added the lump-sum tax (of about $2.8 \%$ of GDP) paid by $\mathrm{O}$ households to make the above figures consistent with a steady state equilibrium in our model.

\subsection{Quantitative Results -}

We continue to assume that transfer payments react to the debt-to-GDP ratio to insure that the government's present value budget constraint is satisfied. We start with a benchmark case in which transfers only depend on lagged transfers and lagged debt/GDP. Figure 4 shows the responses of $\mathrm{C}_{\mathrm{L}, t}, \mathrm{C}_{\mathrm{t}}$, and $\mathrm{Y}_{\mathrm{t}}$ to a one standard deviation shock to transfers and to government purchases. Either shock increases the consumption of L households sufficiently to increase aggregate consumption and output. ${ }^{27}$ The effect of transfers on output suggests, as we will explore below, that counter cyclical transfers can serve as automatic stabilizers in our model. The response

${ }^{27}$ As expected, the consumption of $\mathrm{O}$ households has a negative response (not shown) to either shock. L households, however, have a higher marginal propensity to consume out of current disposable income, and this leads to the increase in aggregate consumption and output. 
of aggregate consumption to a shock to government purchases is positive (but it is not as persistent as some empirical studies find).

We turn next to the possibility that transfers are counter cyclical. In regressions of the log of transfers on its own lagged value, the log of the output gap, and debt/GDP, we do not find statistically significant coefficients on the GDP gap (although our point estimates are negative for almost all the countries). However, when we estimate equations without the debt variable, the coefficients on the gap are in most cases negative and statistically significant.

In Table 7, we compare the numerical solution under our benchmark case, in which the elasticity of transfers with respect to the gap is zero, to two alternatives: one in which the elasticity is -0.35 (our estimate for France) and one in which it is -0.75 (our estimate for Finland). Table 7 reports the standard deviation of various HP filtered variables and the welfare loss (measured in consumption equivalents) that $\mathrm{O}$ households suffer as we move from the benchmark to a given alternative. Stronger counter cyclical transfers do appear to serve as automatic stabilizers in our model; they lead to lower variability of aggregate consumption and output. This comes, however, at the expense of higher consumption variability for optimizing households. Our model suggests that the welfare losses of $\mathrm{O}$ households resulting from counter cyclical transfers are large; when we change the elasticity of transfers with respect to the output gap from the benchmark value of zero to -0.75 , the welfare of $\mathrm{O}$ households drops by over 1.2 percent of their consumption. Since we don't have a welfare measure for L households, we can't assess their gain from counter cyclical transfers.

As noted earlier, we found that the NNS model we used in Canzoneri, Cumby, and Diba (2004a) matched several important features of the data, but failed to match the positive correlations 
of output with inflation and interest rates. We argued that this failure is likely due to the absence - or improper modeling - of traditional IS-type shocks. In Canzoneri, Cumby, and Diba (2004b), we considered a shock to preferences that is often called an IS shock. We found the counterfactual predictions of the model remain, even when that shock is large. The current model with rule of thumb consumers potentially amplifies the effects of fiscal shocks and therefore represents another potential solution to this problem. For the benchmark specification (in which transfers do not respond to the output gap), the correlations of output with inflation and the interest rate are -0.12 and -0.84 , respectively. Although these values are somewhat less counterfactual than those reported in our earlier work, they are still far from the positive correlations found in the data.

Tables $8 \mathrm{~A}$ and $8 \mathrm{~B}$ show the variance decompositions for two of the specifications: the benchmark case (where transfers do not respond to the output gap), and the case with an elasticity of -0.75 . Although we have given a more important role to fiscal shocks, they still fail to account for a sizable fraction of the variability in output and inflation. Our earlier finding that inflation is almost entirely driven by productivity shocks still applies - as does our query about whether or not this result is an artifice of the NNS models we have examined. Moreover, despite the introduction of rule of thumb consumers, fiscal shocks still contribute less than $25 \%$ to the variance of the deficit to GDP ratio when transfers do not respond to the gap, and less than $15 \%$ when they do.

\section{Conclusion}

In this paper, we calibrated an NNS model to three 'typical' countries in the Euro area - an Average Country, a High Debt Country, and a Large Country model. Our model implies that productivity shocks and monetary policy account for much more of the variability in deficit/GDP 
than fiscal shocks do. In this sense, macroeconomic conditions and the common monetary policy impinge on the ability of national fiscal authorities to abide by the deficit limits of the SGP. By contrast, our models suggest that fiscal shocks (of the magnitude we observe in the Euro area) do not impinge on the ECB's ability to control inflation and do not contribute in any significant way to differentials in national inflation rates. The latter conclusion confirms the results of Duarte and Wolman (2002), whose two country model lacked some of the richness of our partial equilibrium models. Our analysis highlights the mechanical origin of this result: inflation in NNS models is driven mostly by real marginal cost, and real marginal cost is driven mostly by productivity shocks.

Our views on policy questions tend to be shaped by what the current generation of models suggests. The NNS is a vast improvement over models that we have used for policy analysis in the past. Our models' implications (summarized in the Introduction) are for now our best assessment of how monetary and fiscal policies interact in the Euro area. However, we know that new models are - and should be - greeted with a healthy dose of scepticism. Some of the current scepticism has manifested itself in empirical challenges to the modeling of fiscal policy in the NNS. In the remainder of this section, we discuss directions of ongoing research, research that may well change our views about the interaction between monetary and fiscal policy within the Euro area.

One empirical challenge comes from the consumption paradox we have already discussed: an increase in government purchases crowds out consumption in our models, but not in the VAR's of Fatas and Mihov (2000, 2001), Blanchard and Perotti (2002) and Canzoneri, Cumby and Diba (2002). The robustness of this VAR result is the subject of ongoing research - Perotti (2004) finds results vary substantially across countries and sample periods; moreover, it remains to be seen why the VAR literature is contradicted by alternative approaches to the identification of fiscal shocks. 
Settling this empirical question is particularly important for our assessment of NNS models with forward looking agents. However, our attempt to introduce rule of thumb consumers suggests that a 'resolution' of the consumption paradox need not reverse our conclusion that fiscal shocks contribute very little to the variability of inflation, and are far from the most important source of variability in deficit/GDP.

A second empirical challenge strikes at the nexus linking productivity, real marginal cost, and inflation in NNS models. This nexus is probably behind the counter cyclical movements of inflation and the nominal interest rate in our models. Our rather rudimentary look at US data in earlier work suggested that inflation and interest rates are procyclical, and the failure of our NNS models (here and elsewhere, see Canzoneri, Cumby and Diba (2004a,b)) on these fronts is rather striking. It remains to be seen if our empirical claim is robust across countries and sample periods, or whether it survives a more careful empirical scrutiny. If it does, then an important challenge to NNS modelers will be to construct models that yield procylical inflation and interest rates. In Canzoneri, Cumby and Diba (2004b), we added an IS-type preference shock, and here we have added 'rule of thumb' consumers. Both extensions move us in the right direction, but neither is strong enough to change the sign of the correlations, or to overcome the dominant role played by productivity shocks. 


\section{References:}

Barro, Robert J., "On the Determination of the Public Debt," Journal of Political Economy 87 no.5, October 1979, pp. 940-971.

Benigno, Pierpaolo and Michael Woodford, "Optimal Monetary and Fiscal Policy: A LinearQuadratic Approach," in Mark Gertler and Kenneth Rogoff(eds.), NBER Macroeconomics Annual 2003.

Blanchard, Olivier J. and Roberto Perotti, "An empirical characterization of the dynamic effects of changes in government spending and taxes on output," Quarterly Journal of Economics, 2002.

Brunila, Anne, Marco Buti, and Daniele Franco (eds.), The Stability and Growth Pact, Palgrave, 2001.

Calvo, Guillermo, “Staggered Prices in a Utility Maximizing Framework,” JME, 12, 1983, pg. 383398.

Canzoneri, Matthew and Behzad Diba, "The Stability and Growth Pact: A Delicate Balance or an Albatross?", Empirica, Volume 26, No. 3, 1999,pg. 241 - 258; reprinted in Brunila, Buti and Franco (2001).

Canzoneri, Matthew, Robert Cumby and Behzad Diba, "Should the European Central Bank and the Federal Reserve Be Concerned About Fiscal Policy?" in Proceedings of a Conference on Rethinking Stabilization Policy, Federal Reserve Bank of Kansas City, Jackson Hole, 2002.

, "Recent Developments in the Macro-economic Stabilization Literature: Is Price Stability a Good Stabilization Strategy?", in Altug Sumra, Jagjit Chadha and Charles Nolan (eds.), Dynamic Macroeconomic Analysis: Theory and Policy in General Equilibrium, Cambridge University Press, 2003.

, “The Cost of Nominal Inertia in NNS Models," mimeo, January 2004a.

,"Price and Wage Inflation Targeting: Variations on a Theme by Erceg, Henderson and Levin," forthcoming in Jon Faust, Athanasios Orphanides and David Reifschneider, eds. Models and Monetary Policy: Research in the Tradition of Dale Henderson, Richard Porter, and Peter Tinsley, 2004b.

Clarida, Richard, Jordi Gali and Mark Gertler, "The Science of Monetary Policy: A New Keynesian Perspective," Journal of Economic Literature, 1999.

Collard, Fabrice and Harris Dellas, "Inflation Targeting," mimeo, 2003. 
Duarte, Margarida and Alexander Wolman, "Regional Inflation in a Currency Union: Fiscal Policy versus Fundamentals," ECB Working Paper \#180, September, 2002.

Erceg, Christopher, Dale Henderson, Andrew Levin, “Optimal Monetary Policy with Staggered Wage and Price Contracts", Journal of Monetary Economics, 46, 2000.

Fatas, Antonio and Ilian Mihov (2000), "Fiscal policy and business cycles: An empirical investigation," mimeo, INSEAD.

Fatas, Antonio and Ilian Mihov (2001), "The effects of fiscal policy on consumption and employment: Theory and Evidence," mimeo, INSEAD.

Gali, Jordi, Mark Gertler, and David Lopez-Salido, "Markups, Gaps, and the Welfare Costs of Business Fluctuations,” NBER Working Paper \#8850, March 2002.

Galì, Jordi, David López-Salido and Javier Vallés, "Understanding the Effects of Government Spending on Consumption," mimeo 2003a.

Galì, Jordi, David López-Salido and Javier Vallés, "Rule-of-Thumb Consumers and the Design of Interest Rate Rules ” mimeo 2003b, forthcoming Journal of Money, Credit and Banking."

Gerlach-Kristen, Petra, "Interest Rate Reaction Functions and the Taylor Rule in the Euro Area," ECB Working Paper no. 258, September 2003.

Goodfriend, Marvin and Robert King, "The New Neoclassical Synthesis and the Role of Monetary Policy," NBER Macroeconomics Annual, MIT Press, 1997, pg. 231-283.

Juillard, Michel, "Dynare: A Program for Solving Rational Expectations Models," CEPREMAP, 2003. (www.cepremap.cnrs.fr/dynare/)

King, Robert and Alexander Wolman, "What Should the Monetary Authority Do When Prices are Sticky?", in John Taylor (ed), Monetary Policy Rules, Chicago Press, 1999.

Kollmann, Robert, “Welfare Maximizing Fiscal and Monetary Policy Rules,” mimeo, March, 2003.

Lucas, Robert, "Macroeconomic Priorities," American Economic Association Presidential Address, American Economic Review, V. 93, No. 1, March, 2003, pg. 1-14.

Perotti, Roberto, "Estimating the Effects of Fiscal Policy in OECD Countries," March, 2004.

Rotemberg, Julio J. and Michael Woodford (1997), "An Optimization Based Econometric Framework for the Evaluation of Monetary Policy," in Ben S. Bernanke and Julio J. Rotemberg (eds) NBER Macroeconomics Annual, pg. 297-346. 
Schmitt-Grohe, Stephanie, and Martin Uribe, "Optimal Fiscal and Monetary Policy under Sticky Prices," forthcoming, Journal of Economic Theory, 2003.

, "Optimal Simple and Implementable Monetary and Fiscal Rules,” NBER Working Paper \# 10253, January 2004.

Smets, Frank and Raf Wouters, "An Estimated Stochastic Dynamic General Equilibrium Model of the Euro Area," ECB Working Paper \#171, August, 2002.

Surico, Paolo, “How Does the ECB Target Inflation?” ECB Working Paper no. 229, May 2003. ,"Shocks and Frictions in US Business Cycles: A Bayesian DSGE Approach," mimeo, May, 2003.

Taylor, John, "Staggered Price and Wage Setting in Macroeconomics," in John Taylor and Michael Woodford (eds.), Handbook of Macroeconomics, vol, 1B, Amsterdam: Elsevier Science B.V., 1999, pg. 1009-1050.

Woodford, Michael, "Price Level Determinacy without Control of a Monetary Aggregate,"Carnegie Rochester Conference Series on Public Policy, 1995, p. 1-46.

, Interest and Prices: Foundations of a Theory of Monetary Policy, Princeton University Press, Princeton, 2003. 


\section{Appendix}

I. The Data

$\mathrm{D}_{\mathrm{t}} \quad$ End-of-period stock of debt. Source: OECD. Gross debt is gross financial liabilities of the general government sector (series GGFL) and net debt is net financial liabilities of the general government sector (series GNFL). Net financial liabilities are equal to gross financial liabilities less the financial assets of the general government sector. The composition of these assets varies across countries and includes cash, bank deposits, loans to the private sector, participations in private sector companies, holdings in public corporations, and foreign exchange reserves. The treatment of the liabilities of the pension plans of government employees also differs across countries

$\mathrm{G}_{\mathrm{t}} \quad$ Government consumption + fixed investment during period t. Source: OECD. Government consumption is series CG and government fixed investment is series IGAA.

$\mathrm{P}_{\mathrm{t}} \quad$ Harmonized consumer price index for the last month in quarter $\mathrm{t}$. Source: Eurostat (series ICP).

$\operatorname{Tr}_{t} \quad$ Government transfer payments during period t. Source: OECD. Transfers are computed as the sum of subsidies, social security payments paid by the government, and other current payments by the government (series TSUB + SSPG + TOCP). Transfers are also the difference between current disbursement and the sum of government consumption and property income paid by the government (series YPG - CG - YPEPG).

$Y_{\mathrm{t}} \quad$ GDP. Source: OECD (series GDP).

$\pi_{t} \quad$ Inflation rate from period $t-1$ to period $t$. Computed as $\log \left(\mathrm{P}_{\mathrm{t}} / \mathrm{P}_{\mathrm{t}-1}\right)$.

$\tau_{\mathrm{w}, \mathrm{t}} \quad$ Average tax rate on labor income. Source: Carey and Rabesona (2002), data provided by David Carey.

$\tau_{c, t} \quad$ Average tax rate on consumption. Source: Carey and Rabesona (2002), data provided by David Carey.

\section{Parameters Used in Calibration}

$\alpha$ : Firms reset prices each quarter with probability $1-\alpha$, so that the mean time between price changes is $(1-\alpha)^{-1}$. Taylor (1999) surveys a large literature and concludes, "price changes and wage changes have about the same average frequency - about one year." This would suggest that we set $\alpha=0.75$. His conclusion is consistent with the results reported in Gali and Gertler (1999) and Spordone (2001). More recently, Begnino and Woodford (2003) state that survey evidence suggests prices are set slightly less frequently than twice a year, which would suggest using a value for $\alpha$ close to 0.5. Bils and Klenow (2002) report evidence that consumer prices are adjusted on average 
considerably more frequently than once a year. Like Rotemberg and Woodford (1997), we set $\alpha$ $=0.67$ so that prices are set on average once each three quarters. This value has the advantage of lying between other values chosen in the literature and is consistent with Blinder's (1994) survey evidence.

$\omega$ : Workers reset wages each quarter with probability 1- $\omega$, so that the mean time between wage changes is $(1-\omega)^{-1}$. We follow the evidence surveyed in Taylor (1999) and set $\omega=0.75$ so that wages are reset annually on average.

$\phi_{\mathrm{p}}$ : We set the elasticity of substitution across goods, $\phi_{\mathrm{p}}=7$, so that the markup of price over marginal cost, $\mu_{\mathrm{p}}=\phi_{\mathrm{p}} /\left(\phi_{\mathrm{p}}-1\right)$ is about 17 percent. Estimates of the markup reported in the literature vary across sectors from about 11 percent to 23 percent. See Bayoumi, Laxton, and Pesenti (2003). Although the evidence suggests that the 15 percent markup used by Rotemberg and Woodford (1997) is a reasonable value for the U.S. manufacturing sector, the evidence cited in Bayoumi, Laxton, and Pesenti indicates that markups outside of manufacturing are higher. As a result we selected a value in the middle of the range of values in Bayoumi, Laxton, and Pesenti.

$\phi_{\mathrm{w}}$ : We set the elasticity of substitution across workers, $\phi_{\mathrm{w}}=7$, so that the wage markup, $\mu_{\mathrm{w}}=$ $\phi_{\mathrm{w}} /\left(\phi_{\mathrm{w}}-1\right)$ is about 17 percent. This is based on evidence on inter-industry wage differentials discussed in Bayoumi, Laxton, and Pesenti (2003).

$v$ : We set the capital share to be 0.25 . Prices are set so that $\mathrm{P}=\mu_{\mathrm{p}} \mathrm{MC}$, and marginal cost can be written as the ratio of wages to the marginal product of labor. Thus $\mathrm{P}=\mu_{\mathrm{p}}[\mathrm{WN} /(1-v) \mathrm{Y}]$ and $(1-v)=\mu_{\mathrm{p}}[\mathrm{WN} / \mathrm{PY}]$. The labor share of compensation (compensation of employees plus two-thirds of proprietors' income relative to GDP - indirect business taxes) in U.S. data averaged about twothirds between 1960:1 - 2003:2. With a markup of about 17 percent, this suggests a value of $v=$ 0.25 .

$\delta$ : We set $\delta=0.025$ so that 2.5 percent of the capital stock depreciates each quarter. This value is widely used in the literature.

$\psi$ : We set the capital adjustment cost parameter, $\psi=8.0$, in order to match the relative volatilities of investment and output as closely to the data as possible.

$\beta$ : We set the discount factor, $\beta=0.99$.

$\chi$ : The reciprocal of the Frisch (or constant $\lambda_{t}$ ) elasticity of labor supply. Empirical estimates of the Frisch elasticity range from 0.05 to 0.35 . So, our benchmark specification $-1 / \chi=0.33$ - is quite conservative for the purposes of our welfare analysis. 
-46-

Table 1: Fiscal Indicators, Averages 1996 - 2001

\begin{tabular}{|l|c|c|c|c|c|}
\hline \multirow{2}{*}{ Country } & & & & \multicolumn{2}{c|}{ Average Tax Rate } \\
\cline { 5 - 6 } & Debt/GDP & G/GDP & Transfers/GDP & Labor Income & Consumption \\
\hline Austria & 64.7 & 21.6 & 24.0 & 41.4 & 18.8 \\
\hline Belgium & 116.3 & 22.8 & 18.7 & 41.7 & 17.9 \\
\hline Finland & 61.4 & 24.2 & 22.3 & 46.2 & 23.9 \\
\hline France & 63.9 & 26.6 & 21.4 & 35.3 & 15.0 \\
\hline Germany & 63.0 & 21.0 & 24.1 & 35.3 & 15.0 \\
\hline Greece & 105.7 & 18.8 & 17.3 & 38.0 & 17.9 \\
\hline Ireland & 53.9 & 15.9 & 12.8 & 25.8 & 21.5 \\
\hline Italy & 116.3 & 20.3 & 19.6 & 39.9 & 16.3 \\
\hline Netherlands & 65.4 & 25.6 & 15.7 & 33.4 & 18.6 \\
\hline Spain & 67.9 & 20.3 & 15.2 & 30.1 & 15.0 \\
\hline Portugal & 59.8 & 23.6 & 18.3 & 24.5 & 20.4 \\
\hline Average Co. & 70.0 & 22.0 & 7.0 & 35.0 & 15.0 \\
\hline High Debt Co. & 100.0 & 22.0 & 10.0 & 40.0 & 17.0 \\
\hline
\end{tabular}


$-47-$

Table 2: Regressions of Euro Area Inflation on Individual Country Inflation

\begin{tabular}{|l|c|c|c|}
\hline Country & Constant & Co. Specific Inflation & S.E.E. \\
\hline Austria & $\begin{array}{c}0.373 \\
(0.050)\end{array}$ & $\begin{array}{c}0.478 \\
(0.070)\end{array}$ & 0.265 \\
\hline Belgium & $\begin{array}{c}0.379 \\
(0.058)\end{array}$ & $\begin{array}{c}0.392 \\
(0.090)\end{array}$ & 0.289 \\
\hline Germany & $\begin{array}{c}0.301 \\
(0.036)\end{array}$ & $\begin{array}{c}0.672 \\
(0.056)\end{array}$ & 0.189 \\
\hline Finland & $\begin{array}{c}0.428 \\
(0.047)\end{array}$ & $\begin{array}{c}0.365 \\
(0.058)\end{array}$ & 0.274 \\
\hline France & $\begin{array}{c}0.260 \\
(0.041)\end{array}$ & $\begin{array}{c}0.739 \\
(0.067)\end{array}$ & 0.200 \\
\hline Greece & $\begin{array}{c}0.389 \\
(0.066)\end{array}$ & $\begin{array}{c}0.118 \\
(0.027)\end{array}$ & 0.310 \\
\hline Ireland & $\begin{array}{c}0.490 \\
(0.073)\end{array}$ & $\begin{array}{c}0.164 \\
(0.077)\end{array}$ & 0.346 \\
\hline Italy & $\begin{array}{c}0.198 \\
(0.070)\end{array}$ & $\begin{array}{c}0.488 \\
(0.072)\end{array}$ & 0.264 \\
\hline Luxembourg & $\begin{array}{c}0.331 \\
(0.055)\end{array}$ & $\begin{array}{c}0.284 \\
(0.075)\end{array}$ & 0.243 \\
\hline Netherlands & $\begin{array}{c}0.550 \\
(0.055)\end{array}$ & $\begin{array}{c}0.099 \\
(0.050)\end{array}$ & 0.348 \\
\hline Portugal & $\begin{array}{c}0.351 \\
(0.056)\end{array}$ & $\begin{array}{c}0.237 \\
(0.039)\end{array}$ & 0.273 \\
\hline Spain & $\begin{array}{c}0.270 \\
(0.073)\end{array}$ & 0.2697 \\
\hline
\end{tabular}

Inflation data are expressed as percent per quarter (inflation $=100 * \log \left(\mathrm{p}_{\mathrm{t}} / \mathrm{p}_{\mathrm{t}-1}\right)$ ).

Sample is 1990:2 to 2004:1 except: Belgium 1991:2, Spain 1992:2, Luxembourg 1995:2. 
Table 3: Average (Small) County

$\begin{array}{lrcc}\text { VARIABLE } & \text { MEAN } & \text { STD } & \text { VAR } \\ \text { consumption } & -0.0383 & 0.0141 & 0.0002 \\ \text { investment } & -1.4519 & 0.0427 & 0.0018 \\ \text { GDP } & 0.4279 & 0.0155 & 0.0002 \\ \text { inflation } & -0.0000 & 0.0039 & 0.0000 \\ \text { interest rate } & 0.0101 & 0.0023 & 0.0000 \\ \text { deficit/GDP } & -0.0001 & 0.0120 & 0.0001 \\ \text { interest/GDP } & 0.0281 & 0.0066 & 0.0000 \\ \text { total rev/GDP } & 0.3191 & 0.0051 & 0.0000 \\ \text { cons tax rev/GDP } & 0.0941 & 0.0029 & 0.0000 \\ \text { wage tax rev/GDP } & 0.2250 & 0.0044 & 0.0000 \\ \text { real wage } & 0.1612 & 0.0078 & 0.0001 \\ \text { employment } & -0.1751 & 0.0146 & 0.0002\end{array}$

\begin{tabular}{|c|c|c|c|c|c|c|c|}
\hline \multicolumn{8}{|c|}{ MATRIX OF CORRELATIONS } \\
\hline Variables & \multirow{2}{*}{\multicolumn{2}{|c|}{ consumption }} & \multicolumn{2}{|c|}{ investment } & \multicolumn{2}{|l|}{ GDP } & infla \\
\hline consumption & & & \multicolumn{2}{|c|}{0.9354} & \multicolumn{2}{|c|}{0.9343} & -0.4 \\
\hline nvestment & \multicolumn{2}{|c|}{0.9354} & \multicolumn{2}{|c|}{1.0000} & \multicolumn{2}{|c|}{0.9612} & -0.27 \\
\hline JDP & \multicolumn{2}{|c|}{0.9343} & \multicolumn{2}{|c|}{0.9612} & \multicolumn{2}{|c|}{1.0000} & 0.3 \\
\hline nflation & \multicolumn{2}{|c|}{-0.4080} & \multicolumn{2}{|c|}{-0.2750} & \multicolumn{2}{|c|}{-0.3116} & . \\
\hline terest rate & \multicolumn{2}{|c|}{-0.9451} & \multicolumn{2}{|c|}{-0.9847} & \multicolumn{2}{|c|}{-0.9267} & .3 \\
\hline \multicolumn{8}{|c|}{ VARIANCE DECOMPOSITION (in percent) } \\
\hline & & $\epsilon_{\mathrm{p}}$ & $\epsilon_{\mathrm{i}}$ & $\epsilon_{\mathrm{g}}$ & $\epsilon_{\tau \mathrm{w}}$ & $\epsilon_{\tau c}$ & $\epsilon_{\mathrm{tr}}$ \\
\hline onsumption & & 61.70 & 30.29 & 1.50 & 0.11 & 6.39 & \\
\hline nvestment & & 51.58 & 47.74 & 0.51 & 0.08 & 0.09 & \\
\hline GDP & & 56.05 & 36.51 & 5.25 & 0.09 & 2.09 & \\
\hline nflation & & 92.24 & 5.18 & 2.04 & 0.09 & 0.46 & \\
\hline nterest rate & & 54.39 & 43.84 & 1.41 & 0.09 & 0.27 & \\
\hline eficit/GDP & & 40.14 & 31.75 & 11.84 & 10.51 & 3.61 & 2.1 \\
\hline terest/GDP & & 52.52 & 45.78 & 1.38 & 0.03 & 0.27 & 0.0 \\
\hline otal tax rev/C & DP & 11.16 & 0.71 & 0.39 & 59.48 & 28.27 & \\
\hline ons tax rev/C & $\mathrm{DP}$ & 0.09 & 0.30 & 2.65 & 0.00 & 96.96 & \\
\hline age tax rev/ & GDP & 15.48 & 1.81 & 0.21 & 82.41 & 0.09 & \\
\hline l wage & & 98.56 & 1.01 & 0.28 & 0.07 & 0.09 & \\
\hline mployment & & 11.29 & 74.02 & 10.35 & 0.19 & 4.16 & \\
\hline
\end{tabular}

NATIONAL WELFARE: $\mathrm{V}=-18.17 ; \mathrm{C}=-1.90 \%$

Note: The data was generated by Dynare, using $1^{\text {st }}$ order approximations; all variables are in logarithms, and have been HP-filtered. V is the intercept of a $2^{\text {nd }}$ order approximation of equation (32); $\mathrm{C}$ is the cost of nominal inertia, expressed as a percentage of consumption. 
Table 4: High Debt County

$\begin{array}{lrcc}\text { VARIABLE } & \text { MEAN } & \text { STD } & \text { VAR } \\ \text { consumption } & -0.0626 & 0.0141 & 0.0002 \\ \text { investment } & -1.4762 & 0.0427 & 0.0018 \\ \text { GDP } & 0.4036 & 0.0155 & 0.0002 \\ \text { inflation } & 0.0000 & 0.0039 & 0.0000 \\ \text { interest rate } & 0.0101 & 0.0023 & 0.0000 \\ \text { deficit/GDP } & -0.0002 & 0.0149 & 0.0002 \\ \text { interest/GDP } & 0.0402 & 0.0094 & 0.0001 \\ \text { total rev/GDP } & 0.3638 & 0.0052 & 0.0000 \\ \text { cons tax rev/GDP } & 0.1067 & 0.0029 & 0.0000 \\ \text { wage tax rev/GDP } & 0.2571 & 0.0045 & 0.0000 \\ \text { real wage } & 0.1612 & 0.0078 & 0.0001 \\ \text { employment } & -0.1994 & 0.0145 & 0.0002\end{array}$

\begin{tabular}{|c|c|c|c|c|c|c|c|}
\hline \multicolumn{8}{|c|}{ MATRIX OF CORRELATIONS } \\
\hline Variables & \multirow{2}{*}{\multicolumn{2}{|c|}{$\begin{array}{l}\text { consumption } \\
1.0000\end{array}$}} & \multicolumn{2}{|c|}{ investment } & \multicolumn{2}{|c|}{ GDP } & infl \\
\hline consumption & & & \multicolumn{2}{|c|}{0.9365} & \multicolumn{2}{|c|}{0.9345} & \\
\hline nvestment & \multicolumn{2}{|c|}{0.9365} & 1.000 & & \multicolumn{2}{|c|}{0.9616} & \\
\hline GDP & \multicolumn{2}{|c|}{0.9345} & \multicolumn{2}{|c|}{0.9616} & \multicolumn{2}{|c|}{1.0000} & \\
\hline nflation & \multicolumn{2}{|c|}{-0.4091} & \multirow{2}{*}{\multicolumn{2}{|c|}{$\begin{array}{l}-0.2751 \\
-0.9847\end{array}$}} & \multicolumn{2}{|c|}{-0.3122} & \\
\hline terest rate & \multicolumn{2}{|c|}{-0.9466} & & & -0.92 & & \\
\hline \multicolumn{8}{|c|}{ VARIANCE DECOMPOSITION (in percent) } \\
\hline \multirow{3}{*}{\multicolumn{2}{|c|}{$\begin{array}{l}\text { consumption } \\
\text { investment }\end{array}$}} & $\epsilon_{\mathrm{p}}$ & $\epsilon_{\mathrm{i}}$ & $\epsilon_{\mathrm{g}}$ & $\epsilon_{\tau \mathrm{w}}$ & $\epsilon_{\tau c}$ & $\epsilon_{\mathrm{tr}}$ \\
\hline & & 61.83 & 30.35 & 1.50 & 0.13 & 6.19 & \\
\hline & & 51.57 & 47.74 & 0.51 & 0.10 & 0.08 & \\
\hline \multicolumn{2}{|l|}{ GDP } & 56.09 & 36.53 & 5.25 & 0.11 & 2.02 & \\
\hline \multicolumn{2}{|l|}{ inflation } & 92.24 & 5.18 & 2.04 & 0.11 & 0.44 & \\
\hline \multicolumn{2}{|l|}{ interest rate } & 54.39 & 43.83 & 1.41 & 0.11 & 0.26 & \\
\hline \multicolumn{2}{|l|}{ deficit/GDP } & 44.52 & 35.20 & 8.31 & 6.68 & 2.33 & 2.5 \\
\hline \multicolumn{2}{|l|}{ interest/GDP } & 52.65 & 45.76 & 1.29 & 0.05 & 0.24 & $0 .($ \\
\hline \multicolumn{2}{|l|}{ total rev/GDP } & 14.12 & 0.90 & 0.48 & 57.67 & 26.83 & \\
\hline \multicolumn{2}{|c|}{ cons tax rev/GDP } & 0.12 & 0.38 & 3.41 & 0.00 & 96.09 & \\
\hline \multicolumn{2}{|c|}{ wage tax rev/GDP } & 19.18 & 2.24 & 0.26 & 78.21 & 0.11 & \\
\hline \multicolumn{2}{|c|}{ real wage } & 98.55 & 1.01 & 0.28 & 0.08 & 0.09 & \\
\hline \multicolumn{2}{|l|}{ employment } & 11.30 & 74.10 & 10.36 & 0.23 & 4.02 & \\
\hline
\end{tabular}

WELFARE: $\mathrm{V}=-19.46$; Cost of nominal inertia $=-1.90 \%$ Does worse than Av co by $1.29 \%$

Note: The data was generated by Dynare, using $1^{\text {st }}$ order approximations; all variables are in logarithms, and have been HP-filtered. V is the intercept of a $2^{\text {nd }}$ order approximation of equation (32); $\mathrm{C}$ is the cost of nominal inertia, expressed as a percentage of consumption. 
Table 5: Large County

$\begin{array}{lrcc}\text { VARIABLE } & \text { MEAN } & \text { STD } & \text { VAR } \\ \text { consumption } & -0.0383 & 0.0203 & 0.0004 \\ \text { investment } & -1.4519 & 0.0601 & 0.0036 \\ \text { GDP } & 0.4279 & 0.0217 & 0.0005 \\ \text { inflation } & -0.0000 & 0.0021 & 0.0000 \\ \text { interest rate } & 0.0101 & 0.0019 & 0.0000 \\ \text { deficit/GDP } & -0.0001 & 0.0124 & 0.0002 \\ \text { interest/GDP } & 0.0281 & 0.0056 & 0.0000 \\ \text { total rev/GDP } & 0.3191 & 0.0050 & 0.0000 \\ \text { cons tax rev/GDP } & 0.0941 & 0.0029 & 0.0000 \\ \text { wage tax rev/GDP } & 0.2250 & 0.0041 & 0.0000 \\ \text { real wage } & 0.1612 & 0.0072 & 0.0001 \\ \text { employment } & -0.1751 & 0.0149 & 0.0002\end{array}$

\begin{tabular}{|c|c|c|c|c|c|c|c|}
\hline \multicolumn{8}{|c|}{ MATRIX OF CORRELATIONS } \\
\hline Variables & \multirow{2}{*}{\multicolumn{2}{|c|}{ consumption }} & \multicolumn{2}{|c|}{ investment } & \multicolumn{2}{|c|}{ GDP } & infl \\
\hline consumption & & & \multicolumn{2}{|c|}{0.9691} & \multicolumn{2}{|c|}{0.9682} & \\
\hline nvestment & \multicolumn{2}{|c|}{0.9691} & \multicolumn{2}{|c|}{1.0000} & \multicolumn{2}{|c|}{0.9798} & \\
\hline GDP & \multicolumn{2}{|c|}{0.9682} & \multicolumn{2}{|c|}{0.9798} & \multicolumn{2}{|c|}{1.0000} & \\
\hline inflation & \multicolumn{2}{|c|}{-0.6454} & \multicolumn{2}{|c|}{-0.6613} & \multicolumn{2}{|c|}{-0.6392} & \\
\hline iterest rate & \multicolumn{2}{|c|}{-0.9050} & \multicolumn{2}{|c|}{-0.9395} & \multicolumn{2}{|c|}{-0.9109} & \\
\hline \multicolumn{8}{|c|}{ VARIANCE DECOMPOSITION (in percent) } \\
\hline & & $\epsilon_{\mathrm{p}}$ & $\epsilon_{\mathrm{i}}$ & $\epsilon_{\mathrm{g}}$ & $\epsilon_{\tau \mathrm{W}}$ & $\epsilon_{\tau c}$ & $\epsilon_{\mathrm{tr}}$ \\
\hline consumption & & 90.12 & $\begin{array}{l}5.18 \\
851\end{array}$ & & 0.16 & 2.17 & \\
\hline investment & & & 8.51 & & & & \\
\hline GDP & & 92.03 & 6.60 & 0.70 & 0.15 & 0.53 & \\
\hline nflation & & 91.23 & 6.84 & 1.25 & 0.03 & 0.66 & \\
\hline interest rate & & 72.58 & 25.61 & 1.21 & 0.05 & 0.56 & \\
\hline leficit/GDP & & 59.63 & 11.12 & 13.65 & 9.32 & 4.28 & 2.0 \\
\hline interest/GDP & & 73.76 & 24.39 & 1.28 & 0.01 & 0.54 & 0.0 \\
\hline total rev/GDP & & 6.14 & 0.27 & 0.58 & 62.42 & 30.59 & \\
\hline cons tax rev/G & DP & 0.38 & 0.11 & 2.47 & 0.00 & 97.05 & \\
\hline wage tax rev/ & JDP & 7.15 & 0.74 & 0.05 & 92.01 & 0.05 & \\
\hline eal wage & & 99.28 & 0.38 & 0.15 & 0.12 & 0.06 & \\
\hline employment & & 70.07 & 24.93 & 2.51 & 0.57 & 1.92 & \\
\hline
\end{tabular}

WELFARE: $V=-16.70$; Cost of nominal inertia $=-0.43 \%$ does better than Av co by $1.47 \%$

Note: The data was generated by Dynare, using $1^{\text {st }}$ order approximations; all variables are in logarithms, and have been HP-filtered. V is the intercept of a $2^{\text {nd }}$ order approximation of equation (32); $\mathrm{C}$ is the cost of nominal inertia, expressed as a percentage of consumption. 
$-51-$

Table 6: Fiscal Rules to Reduce the Volatility of Deficit/GDP

\begin{tabular}{|l|c|c|c|}
\hline \multirow{2}{*}{$\begin{array}{c}\text { Variable } \\
\text { Vesponse }\end{array}$} & $\begin{array}{c}\text { No } \\
\text { Renh Debt Country }\end{array}$ \\
\cline { 3 - 4 } Deficit/GDP & 1.46 & 1.00 & Response in: \\
\hline Output & 1.54 & 1.60 & 1.00 \\
\hline Hours Worked & 1.45 & 1.46 & 1.77 \\
\hline Consumption & 1.40 & 1.47 & 1.10 \\
\hline Inflation & 0.39 & 0.40 & 0.36 \\
\hline Change in Welfare & & -0.55 & 0.56 \\
\hline
\end{tabular}

Notes:

1. Results for economic variables are unconditional standard deviation, in percentages

2. Results for welfare are in consumption equivalents, in percentages. 
Table 7: Standard Deviations and Welfare Losses Under Alternative Transfer Schemes

\begin{tabular}{|c|c|c|c|}
\hline $\begin{array}{c}\text { Output-Gap } \\
\text { Elasticity of } \\
\text { Transfers }\end{array}$ & 0 & -0.35 & -0.75 \\
\hline $\mathrm{SD}\left(\mathrm{C}_{\mathrm{O}}\right)$ & 0.0136 & 0.0143 & 0.0150 \\
\hline $\mathrm{SD}\left(\mathrm{C}_{\mathrm{L}}\right)$ & 0.0189 & 0.0167 & 0.0173 \\
\hline $\mathrm{SD}(\mathrm{C})$ & 0.0131 & 0.0122 & 0.0114 \\
\hline $\mathrm{SD}(\mathrm{I})$ & 0.0540 & 0.0518 & 0.0503 \\
\hline $\mathrm{SD}(\mathrm{Y})$ & 0.0165 & 0.0155 & 0.0146 \\
\hline $\mathrm{SD}(\mathrm{N})$ & 0.0179 & 0.0173 & 0.0167 \\
\hline $\mathrm{SD}(\mathrm{W} / \mathrm{P})$ & 0.0079 & 0.0080 & 0.0081 \\
\hline $\mathrm{SD}(\mathrm{i})$ & 0.0024 & 0.0025 & 0.0027 \\
\hline $\mathrm{SD}\left(\pi_{\mathrm{c}}\right)$ & 0.0042 & 0.0045 & 0.0048 \\
\hline $\mathrm{SD}(\mathrm{S} / \mathrm{Y})$ & 0.0121 & 0.0131 & 0.0142 \\
\hline $\mathrm{Welfare} \mathrm{Loss}$ & & 0.569 & 1.206 \\
\hline
\end{tabular}

Note: Standard deviations are for HP filtered variables in the model of Section 7; these figures are calculated using the first order approximation to the model. In our benchmark specification, the elasticity of transfers with respect to the output gap is zero. The alternative specifications set this elasticity to -0.35 and -0.75 . The welfare losses of optimizing households are expressed as percentages of their consumption, as we go from the benchmark to each alternative; these losses are calculated using the second order approximation to the model. 
$-53-$

Table 8A: Variance Decomposition for Benchmark Specification of Table 7.

$\begin{array}{lcrrrrr} & \epsilon_{\mathrm{p}} & \epsilon_{\mathrm{i}} & \epsilon_{\mathrm{g}} & \epsilon_{\mathrm{tr}} & \epsilon_{\tau \mathrm{w}} & \epsilon_{\tau \mathrm{c}} \\ \mathrm{C}_{\mathrm{O}} & 64.21 & 27.01 & 1.21 & 0.21 & 0.18 & 7.18 \\ \mathrm{C}_{\mathrm{L}} & 12.72 & 16.73 & 5.46 & 35.48 & 17.21 & 12.41 \\ \mathrm{C} & 41.45 & 30.46 & 0.70 & 8.57 & 5.76 & 13.06 \\ \mathrm{I} & 47.95 & 50.64 & 1.04 & 0.18 & 0.01 & 0.18 \\ \mathrm{Y} & 44.26 & 39.87 & 9.23 & 2.16 & 1.35 & 3.13 \\ \mathrm{~N} & 15.73 & 60.92 & 13.52 & 3.18 & 2.03 & 4.63 \\ \mathrm{~W} / \mathrm{P} & 97.79 & 1.23 & 0.49 & 0.11 & 0.24 & 0.14 \\ \mathrm{i} & 56.56 & 39.85 & 2.63 & 0.45 & 0.08 & 0.43 \\ \pi_{\mathrm{c}} & 89.79 & 5.43 & 3.42 & 0.62 & 0.09 & 0.65 \\ \mathrm{~S} / \mathrm{Y} & 43.14 & 33.02 & 10.56 & 2.33 & 7.90 & 3.06\end{array}$

Table 8B: Variance Decomposition for Specification of Table 7 with Elasticity of $\mathbf{- 0 . 7 5 .}$

\begin{tabular}{lcrrrrr} 
& $\epsilon_{\mathrm{p}}$ & \multicolumn{1}{c}{$\epsilon_{\mathrm{i}}$} & $\epsilon_{\mathrm{g}}$ & $\epsilon_{\mathrm{tr}}$ & $\epsilon_{\tau \mathrm{w}}$ & \multicolumn{1}{c}{$\epsilon_{\tau \mathrm{c}}$} \\
$\mathrm{C}_{\mathrm{O}}$ & 68.70 & 24.22 & 0.53 & 0.09 & 0.24 & 6.22 \\
$\mathrm{C}_{\mathrm{L}}$ & 21.36 & 15.42 & 3.85 & 33.07 & 16.55 & 9.75 \\
$\mathrm{C}$ & 40.36 & 28.38 & 1.60 & 9.17 & 6.31 & 14.19 \\
$\mathrm{I}$ & 47.46 & 51.69 & 0.58 & 0.11 & 0.04 & 0.12 \\
$\mathrm{Y}$ & 43.94 & 40.18 & 9.17 & 2.18 & 1.33 & 3.21 \\
$\mathrm{~N}$ & 23.03 & 55.91 & 12.10 & 2.88 & 1.82 & 4.26 \\
$\mathrm{~W} / \mathrm{P}$ & 98.21 & 1.11 & 0.32 & 0.07 & 0.19 & 0.09 \\
$\mathrm{i}$ & 63.91 & 34.57 & 1.08 & 0.18 & 0.08 & 0.18 \\
$\pi_{\mathrm{c}}$ & 95.30 & 2.48 & 1.57 & 0.29 & 0.06 & 0.31 \\
$\mathrm{~S} / \mathrm{Y}$ & 56.80 & 30.07 & 5.04 & 1.16 & 5.31 & 1.61
\end{tabular}




\section{Figure 1A: Average (Small) Country, Productivity Shock}
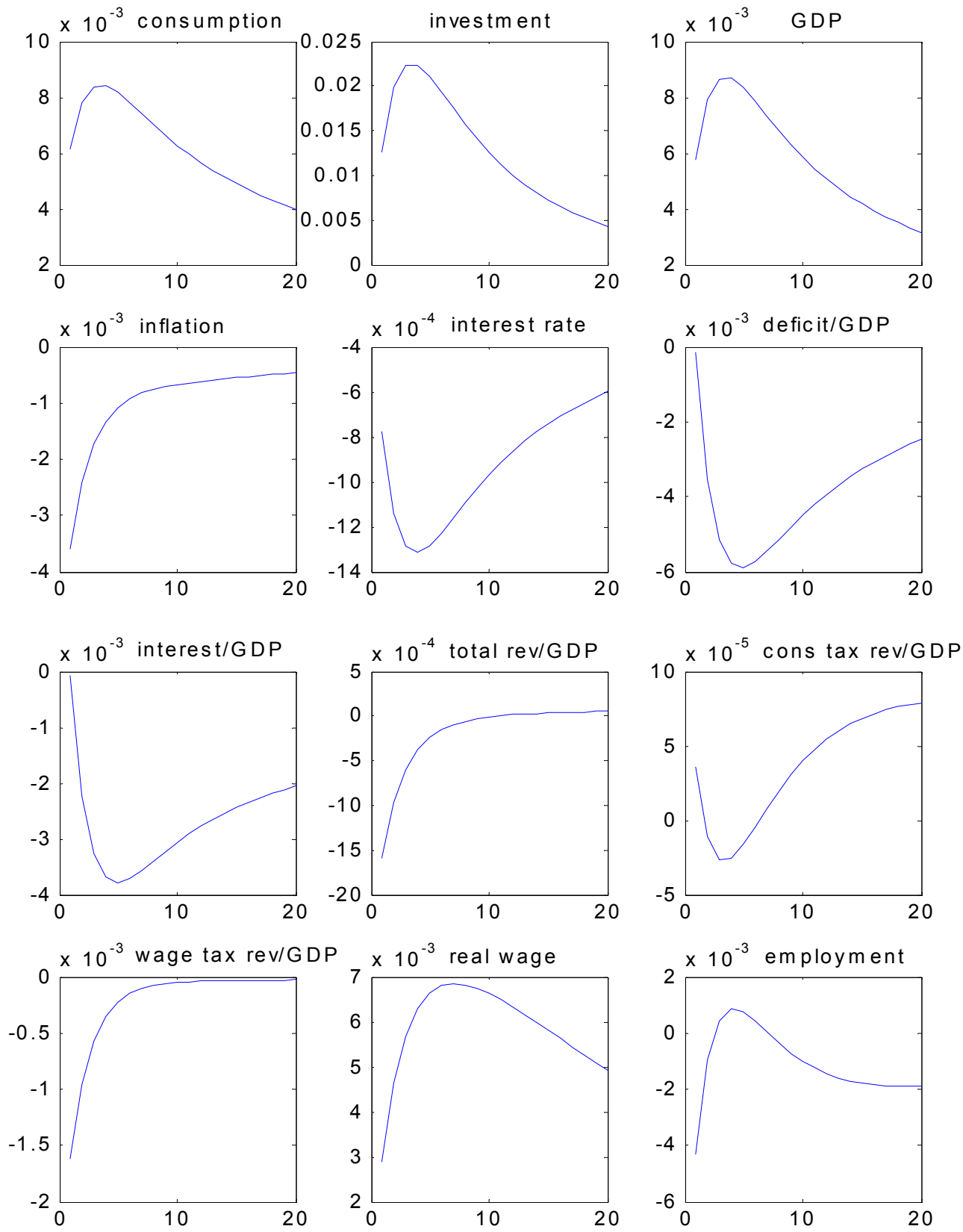

Note: Impulse response functions generated by Dynare, using $1^{\text {st }}$ order approximations. 


\section{Figure 1B: Average (Small) Country, Interest Rate Shock}
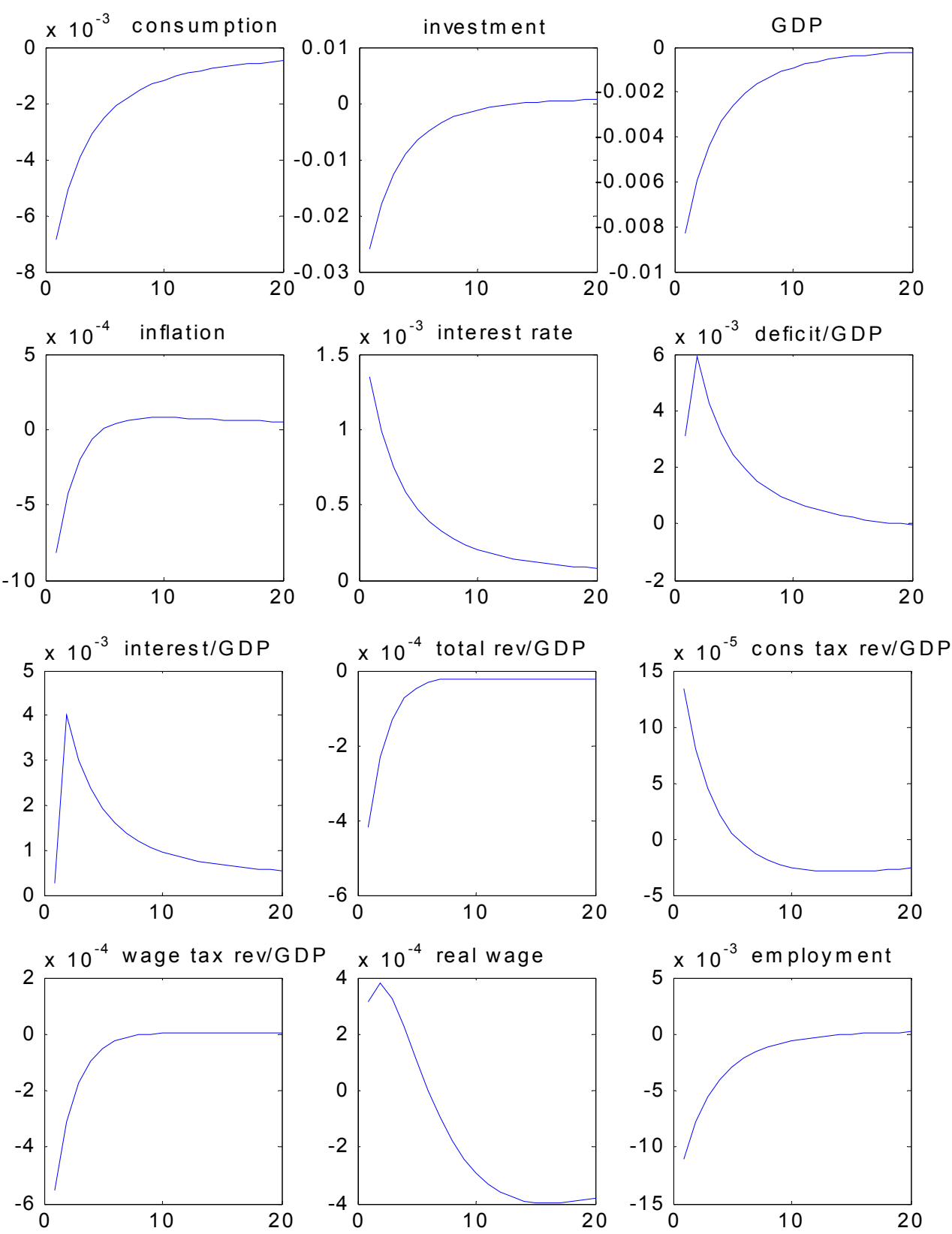

Impulse response functions generated by Dynare, using $1^{\text {st }}$ order approximations.

Note: 
Figure 1C: Average (Small) Country, Government Purchases Shock
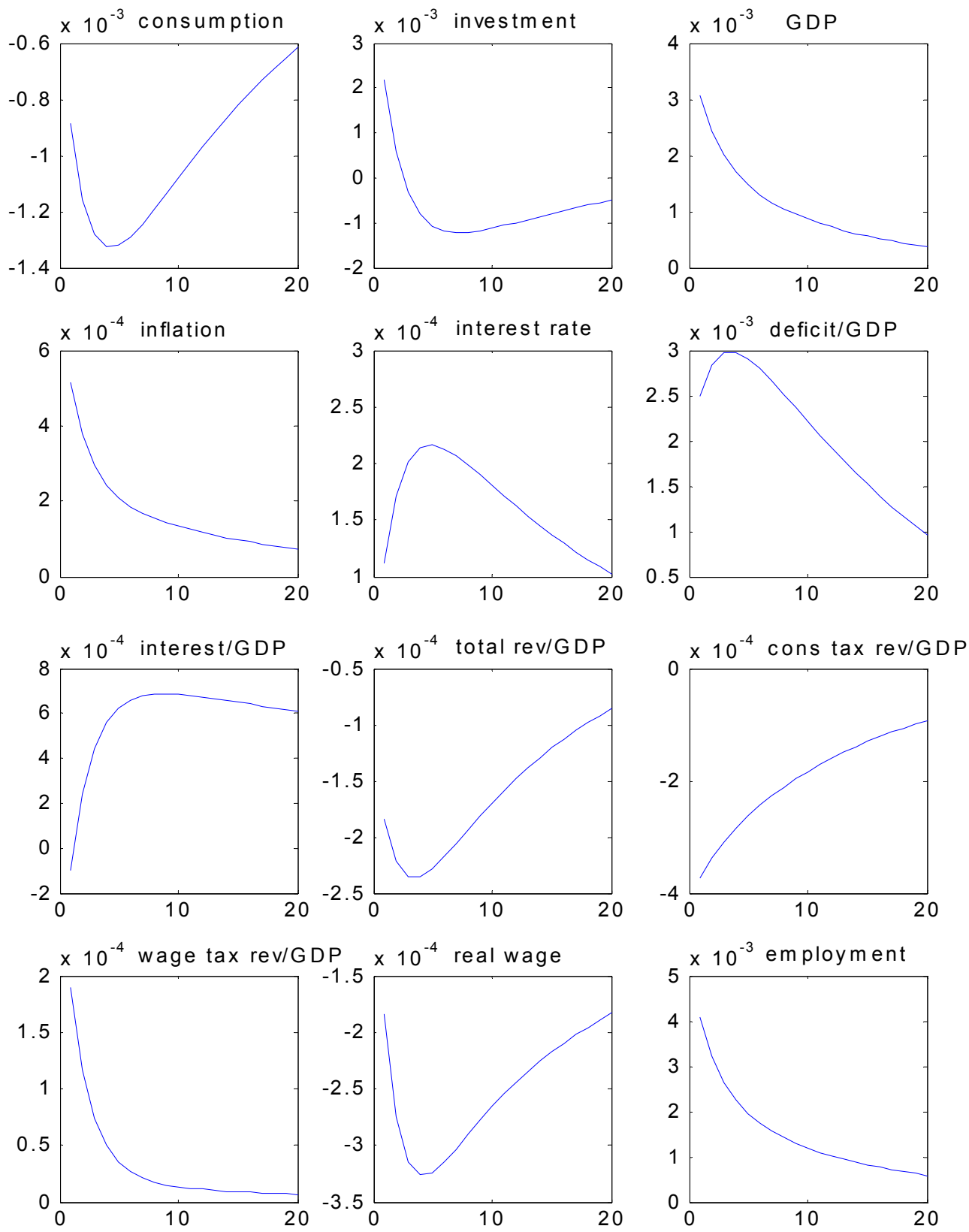

Impulse response functions generated by Dynare, using $1^{\text {st }}$ order approximations.

Note: 
$-57-$

Figure 1D: Average (Small) Country, Consumption Tax Shock
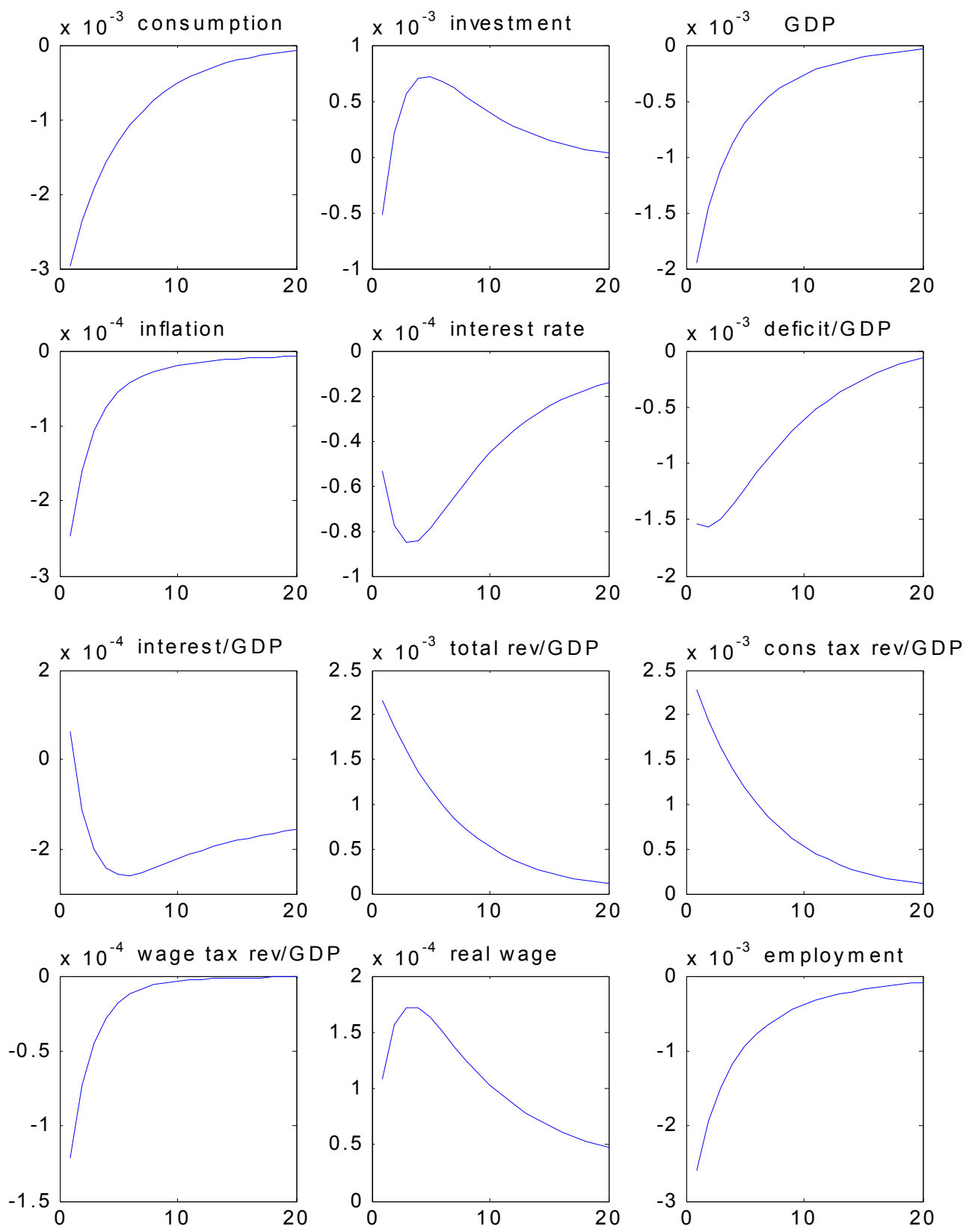

Impulse response functions generated by Dynare, using $1^{\text {st }}$ order approximations.

Note: 


\section{Figure 1E: Average (Small) Country, Labor Tax Shock}
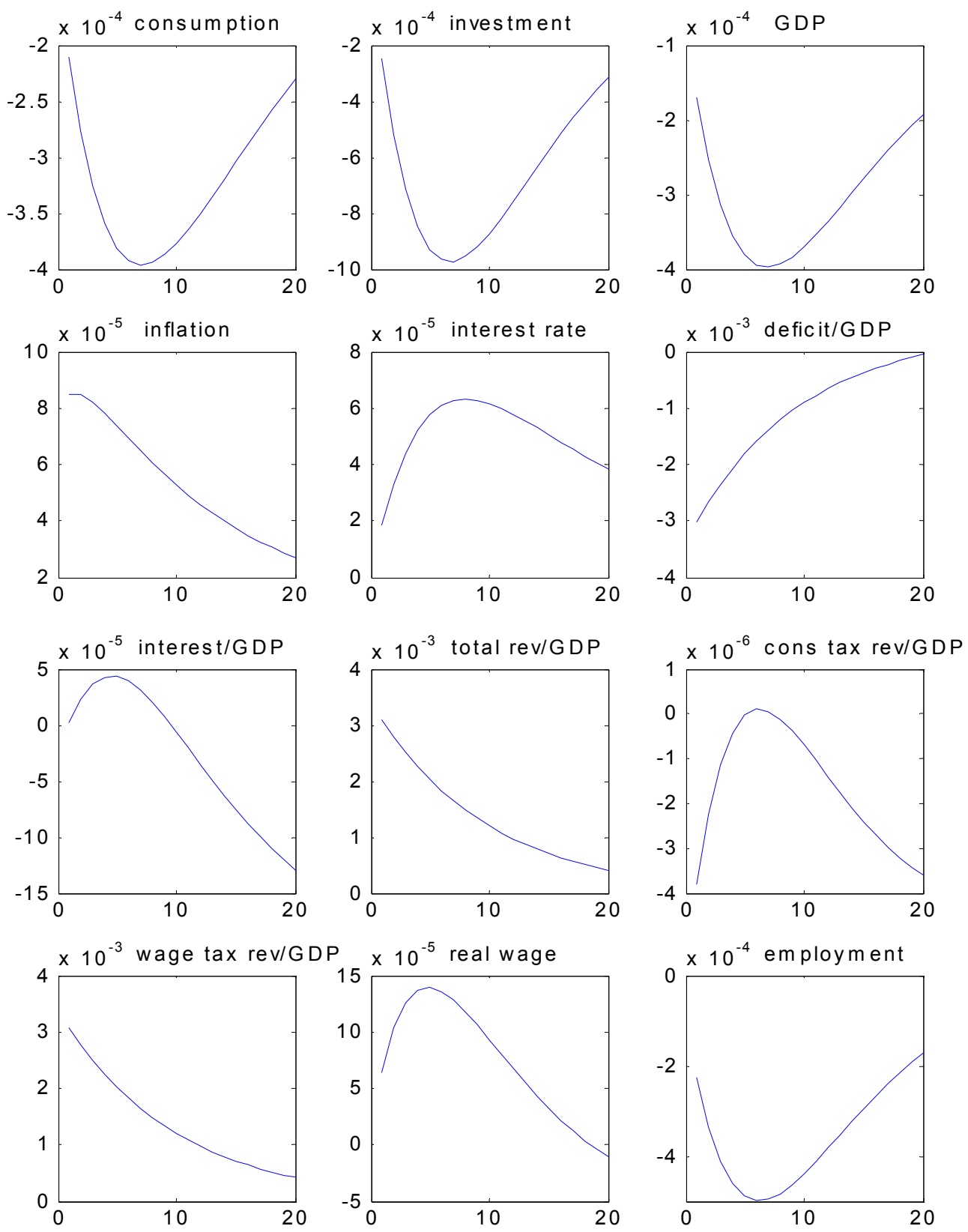

Impulse response functions generated by Dynare, using $1^{\text {st }}$ order approximations.

Note: 


\section{Figure 2A: High Debt Country, Productivity Shock}
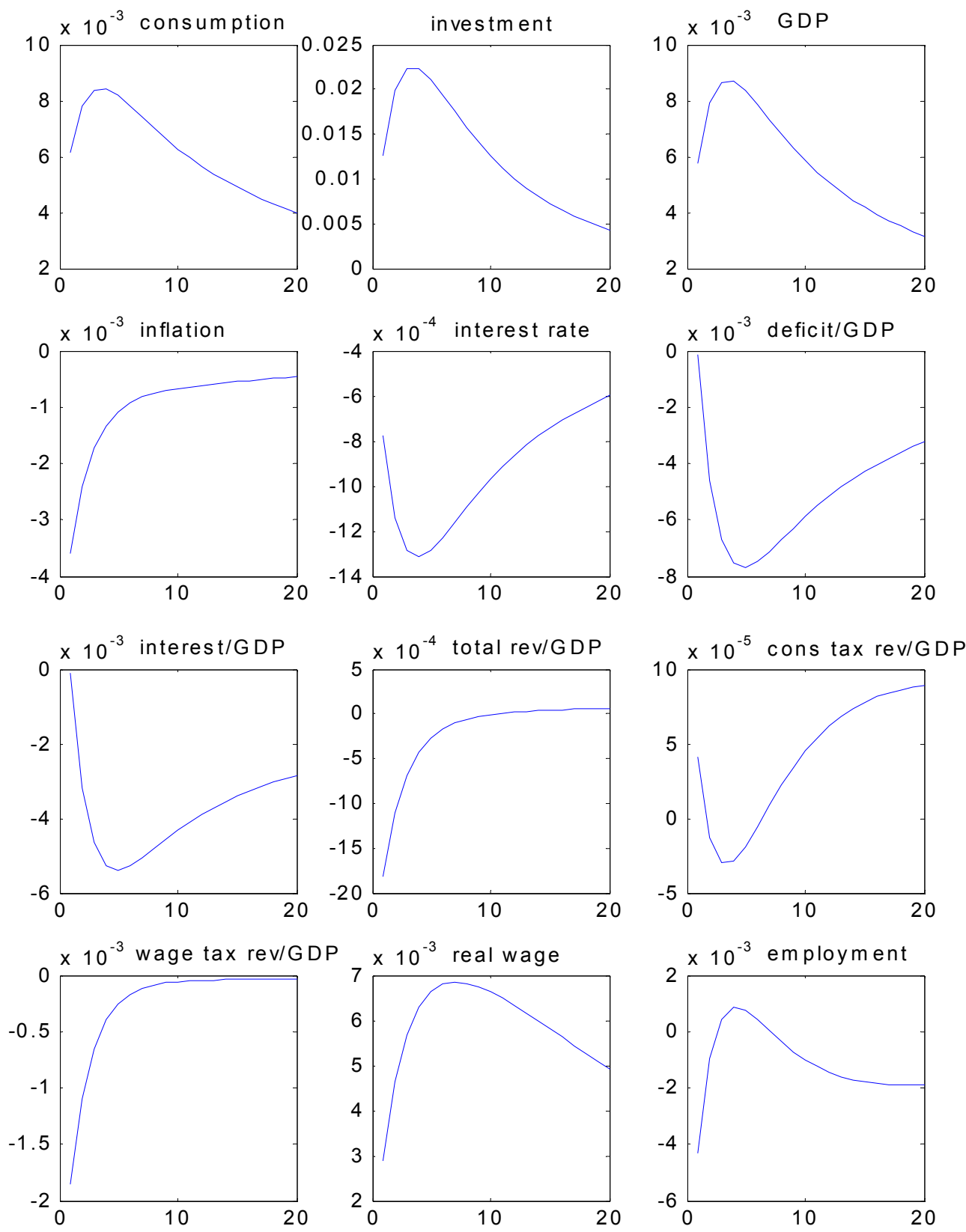

Impulse response functions generated by Dynare, using $1^{\text {st }}$ order approximations.

Note: 
$-60-$

\section{Figure 2B: High Debt Country, Interest Rate Shock}
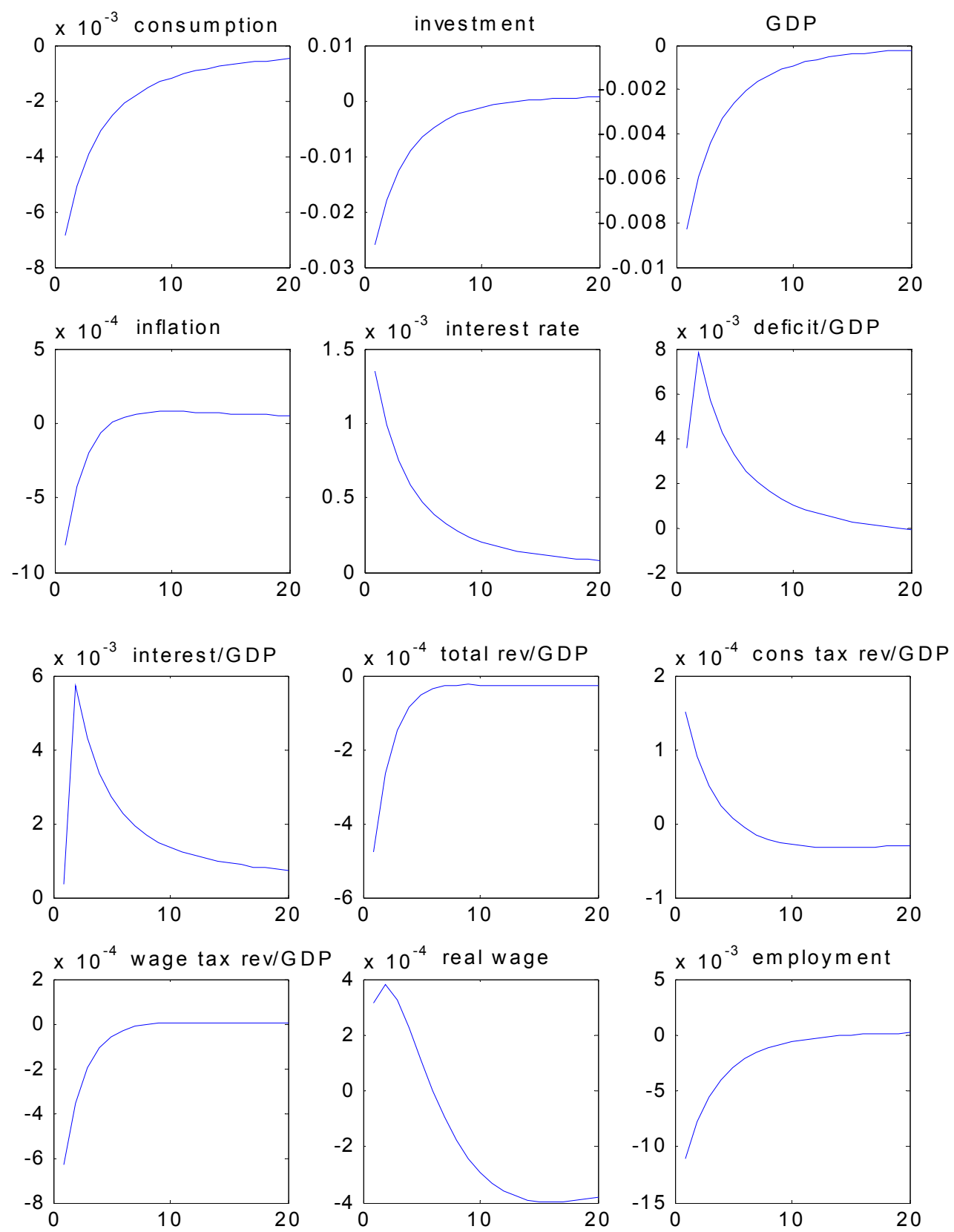

Note: Impulse response functions generated by Dynare, using $1^{\text {st }}$ order approximations. 
Figure 2C: High Debt Country, Government Purchases Shock
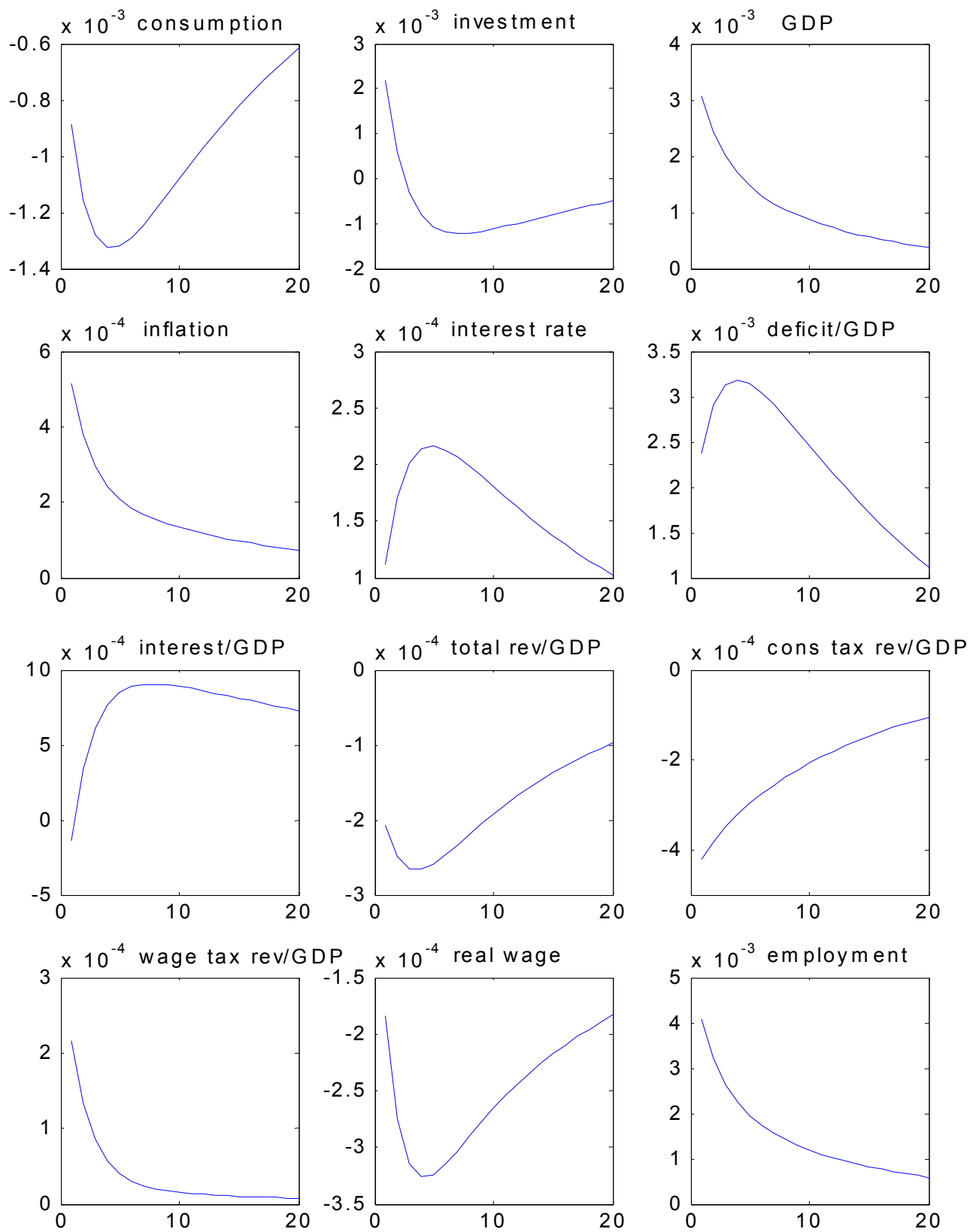

Note: Impulse response functions generated by Dynare, using $1^{\text {st }}$ order approximations. 


\section{Figure 2D: High Debt Country, Consumption Tax Shock}
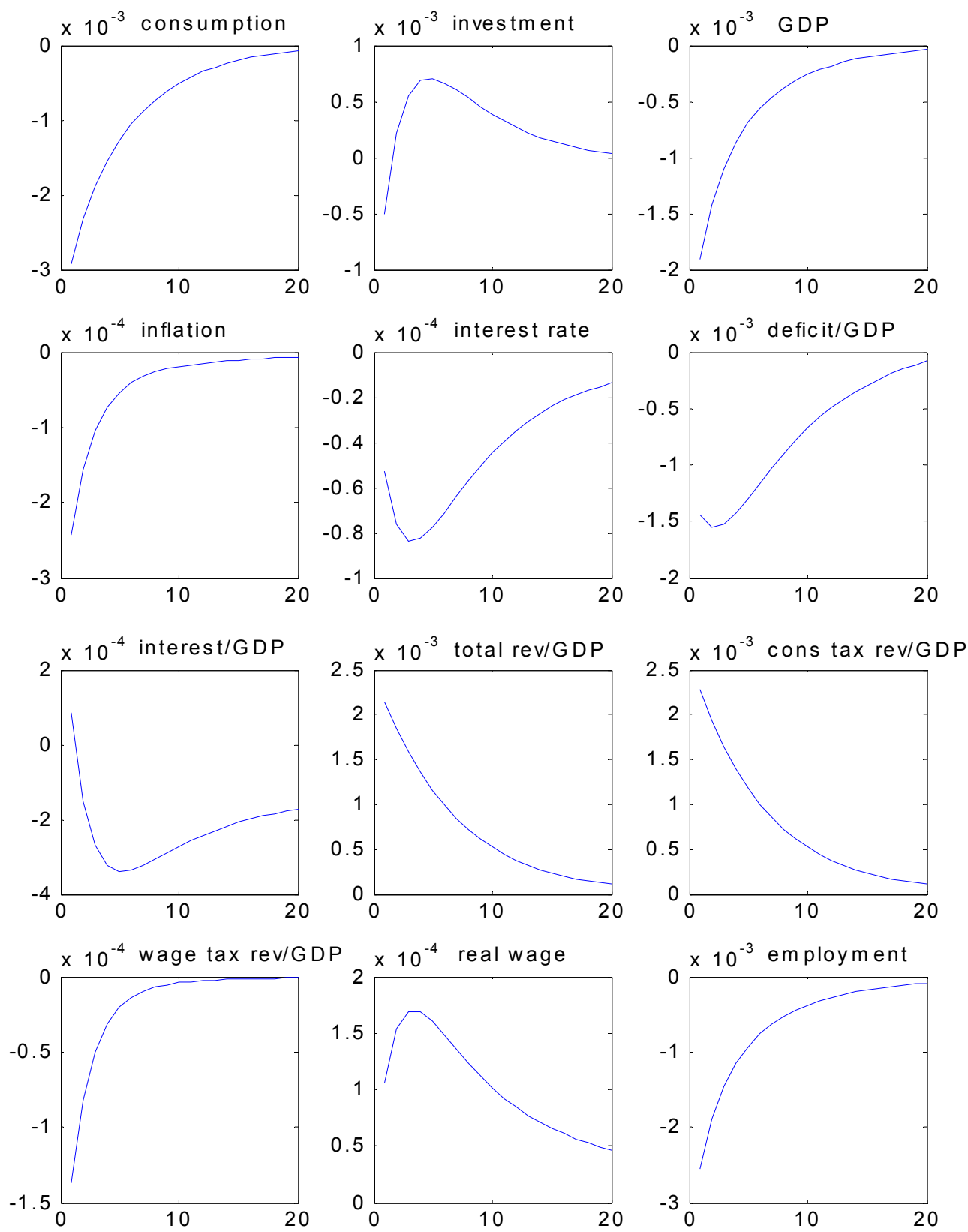

Impulse response functions generated by Dynare, using $1^{\text {st }}$ order approximations.

Note: 


\section{Figure 2E: High Debt Country, Labor Tax Shock}
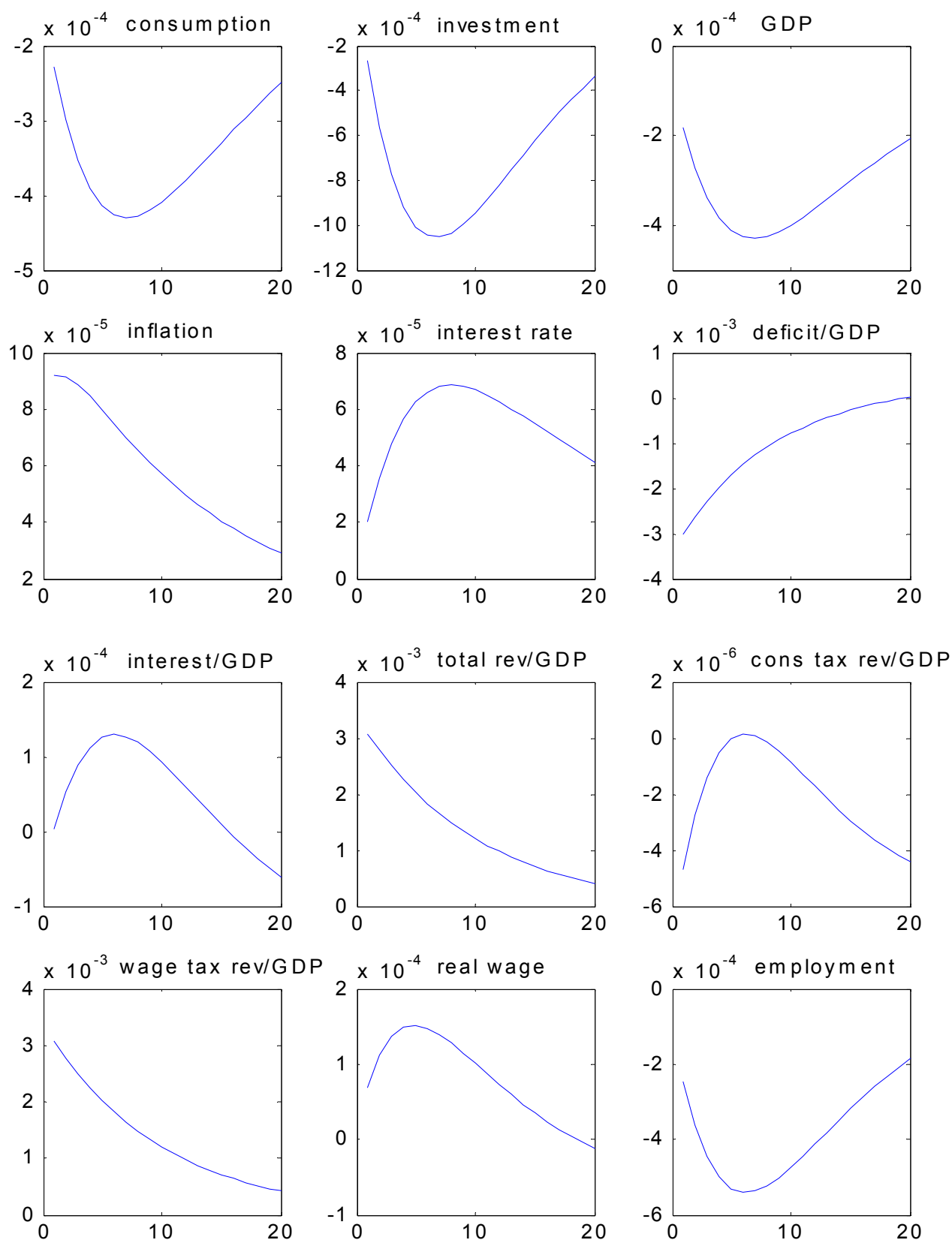

Note: Impulse response functions generated by Dynare, using $1^{\text {st }}$ order approximations. 


\section{Figure 3A: Large Country, Productivity Shock}
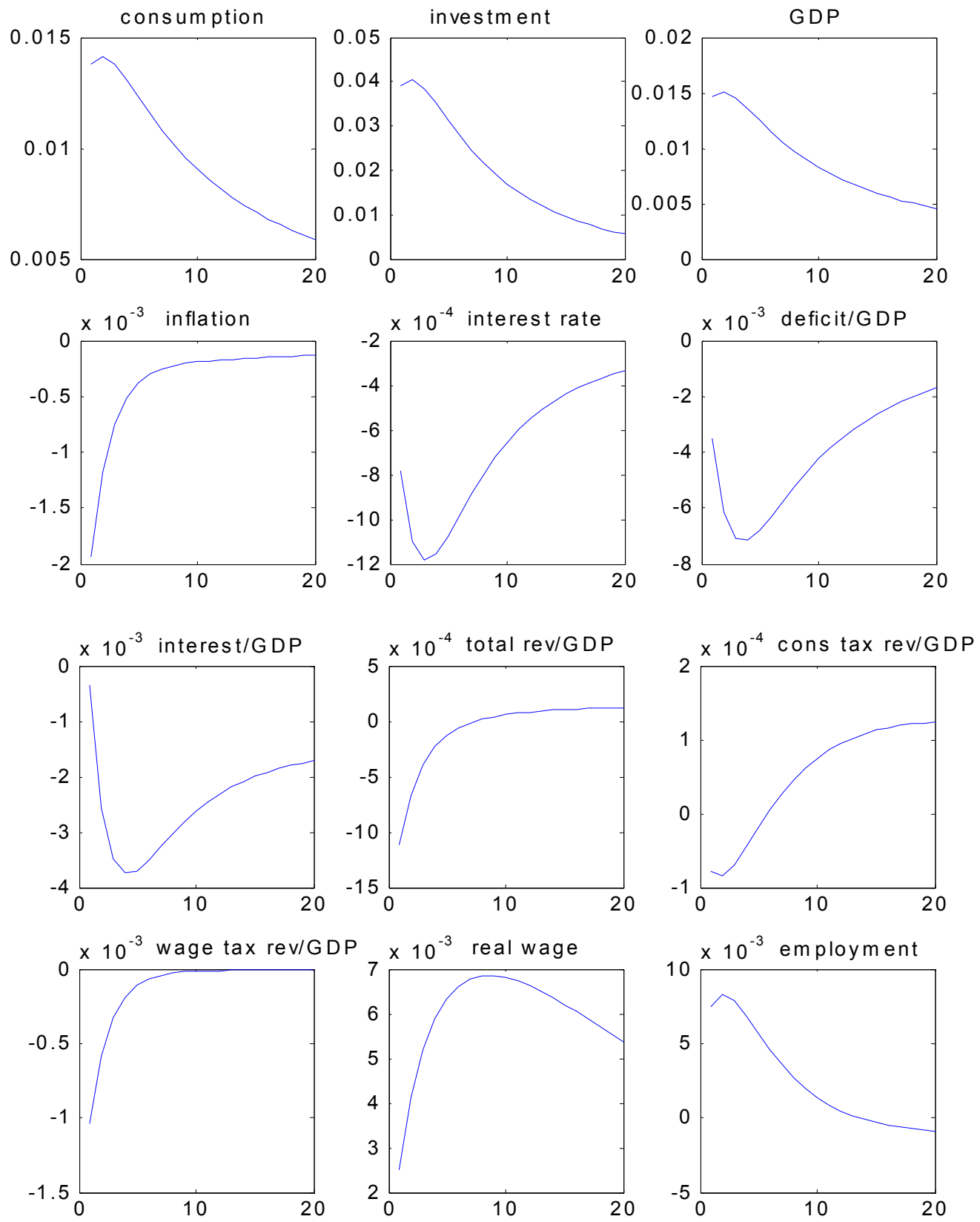

Note: Impulse response functions generated by Dynare, using $1^{\text {st }}$ order approximations. 
Figure 3B: Large Country, Interest Rate Shock
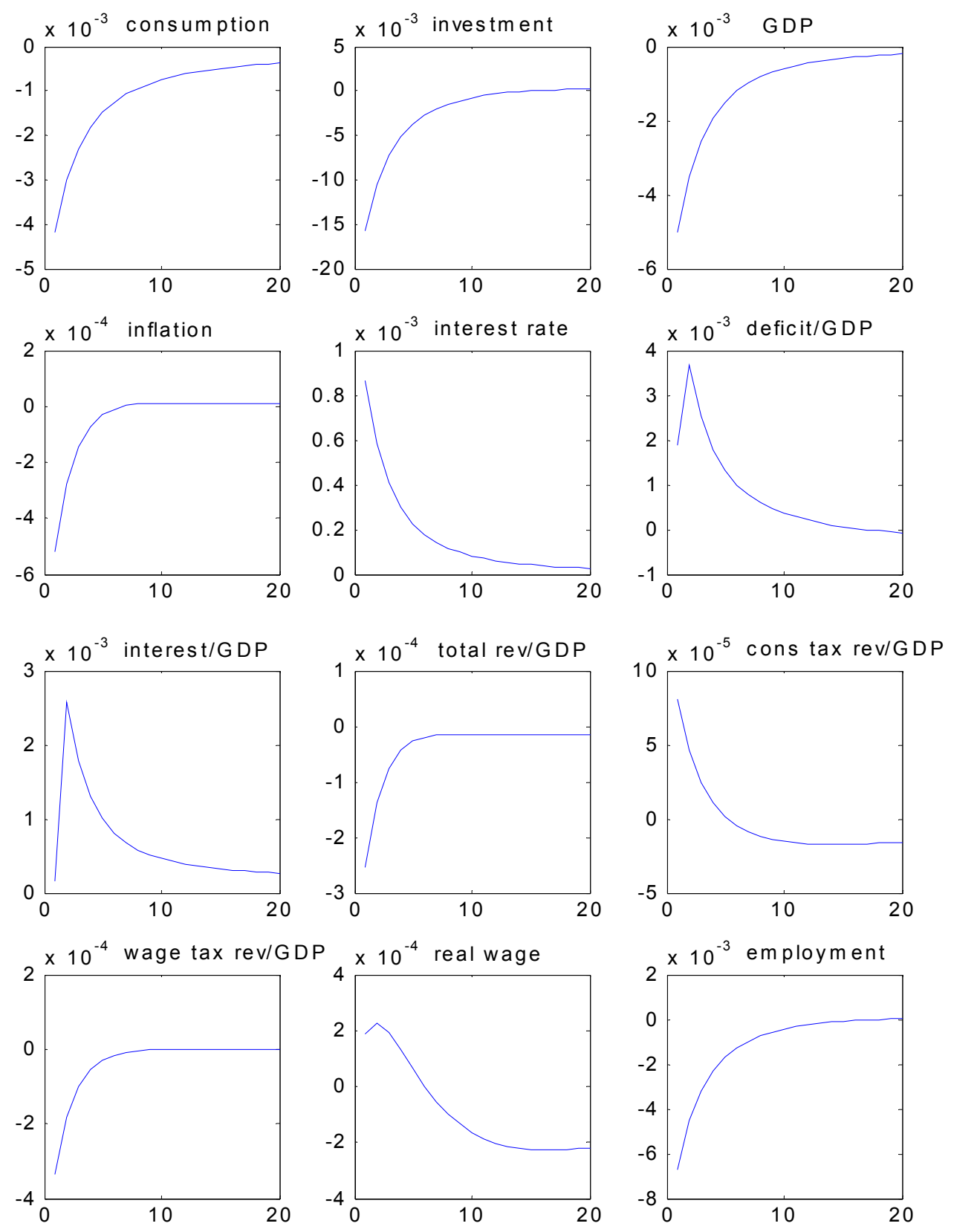

Note: Impulse response functions generated by Dynare, using $1^{\text {st }}$ order approximations. 


\section{Figure 3C: Large Country, Government Purchases Shock}
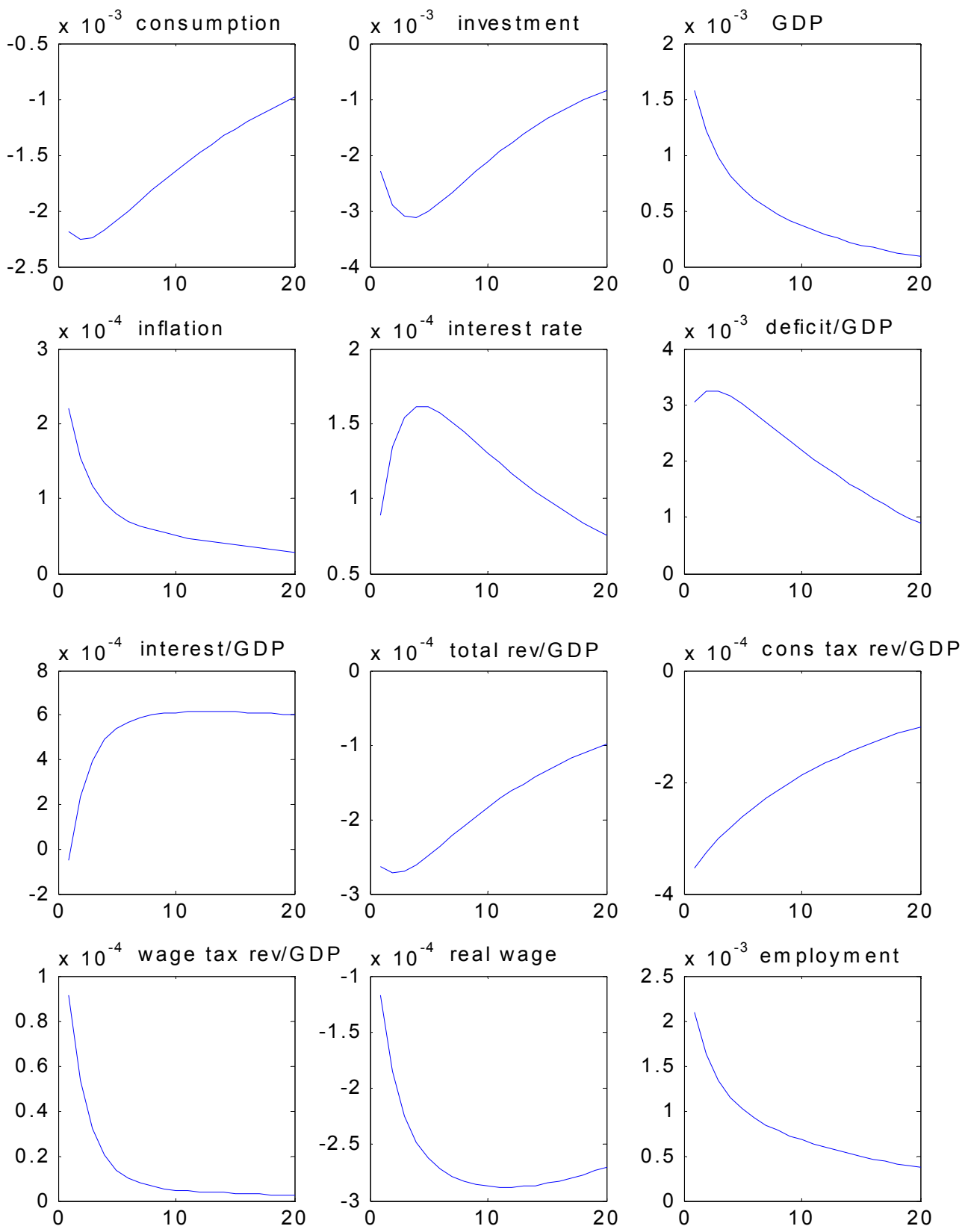

Note: Impulse response functions generated by Dynare, using $1^{\text {st }}$ order approximations. 


\section{Figure 3D: Large Country, Consumption Tax Shock}
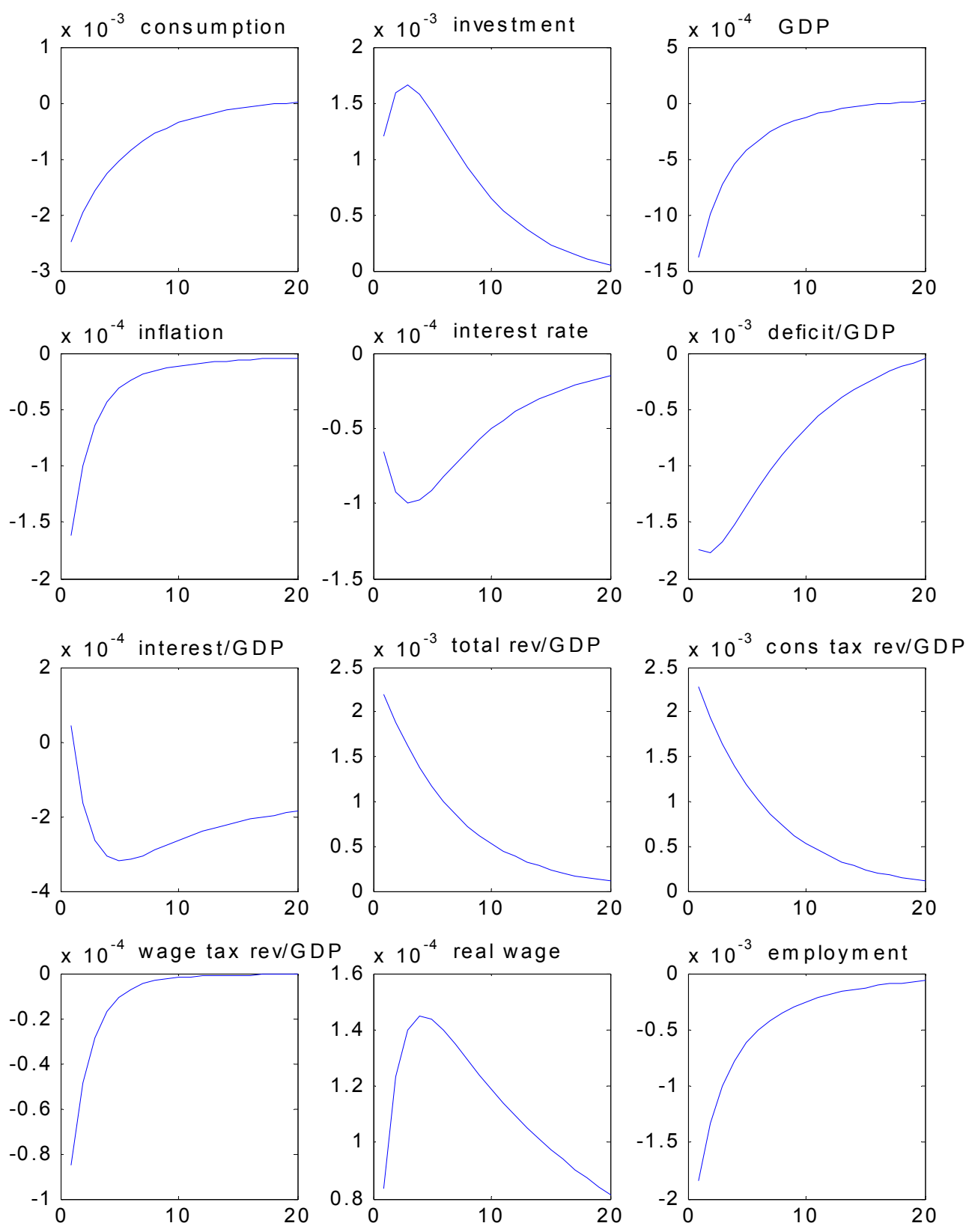

Note: Impulse response functions generated by Dynare, using $1^{\text {st }}$ order approximations. 


\section{Figure 3E: Large Country, Labor Tax Shock}
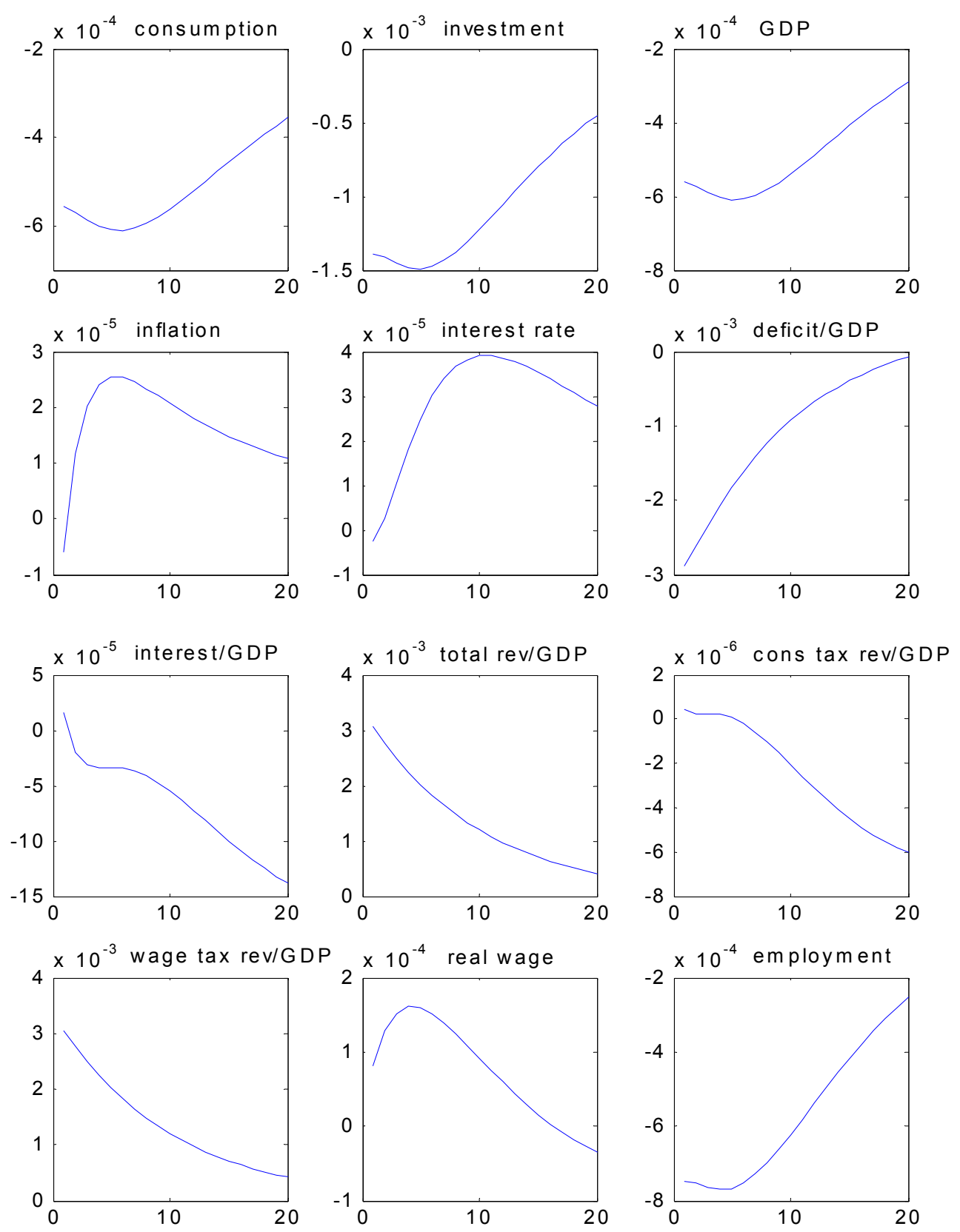

Note: Impulse response functions generated by Dynare, using $1^{\text {st }}$ order approximations. 
-69-

Figure 4A: Model with Non-Optimizers, Transfer Shock
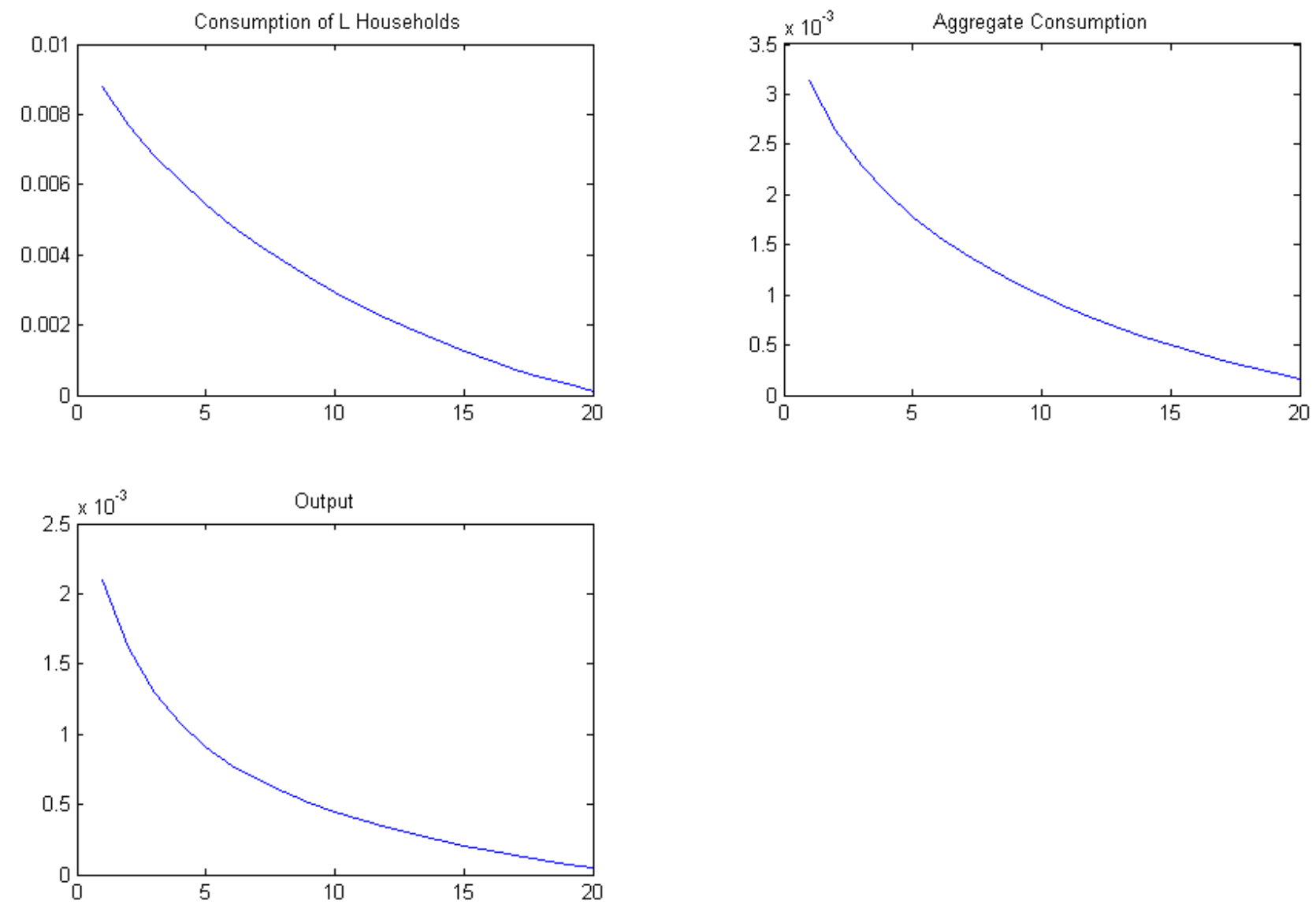
Figure 4B: Model with Non-Optimizers, Government Purchases Shock
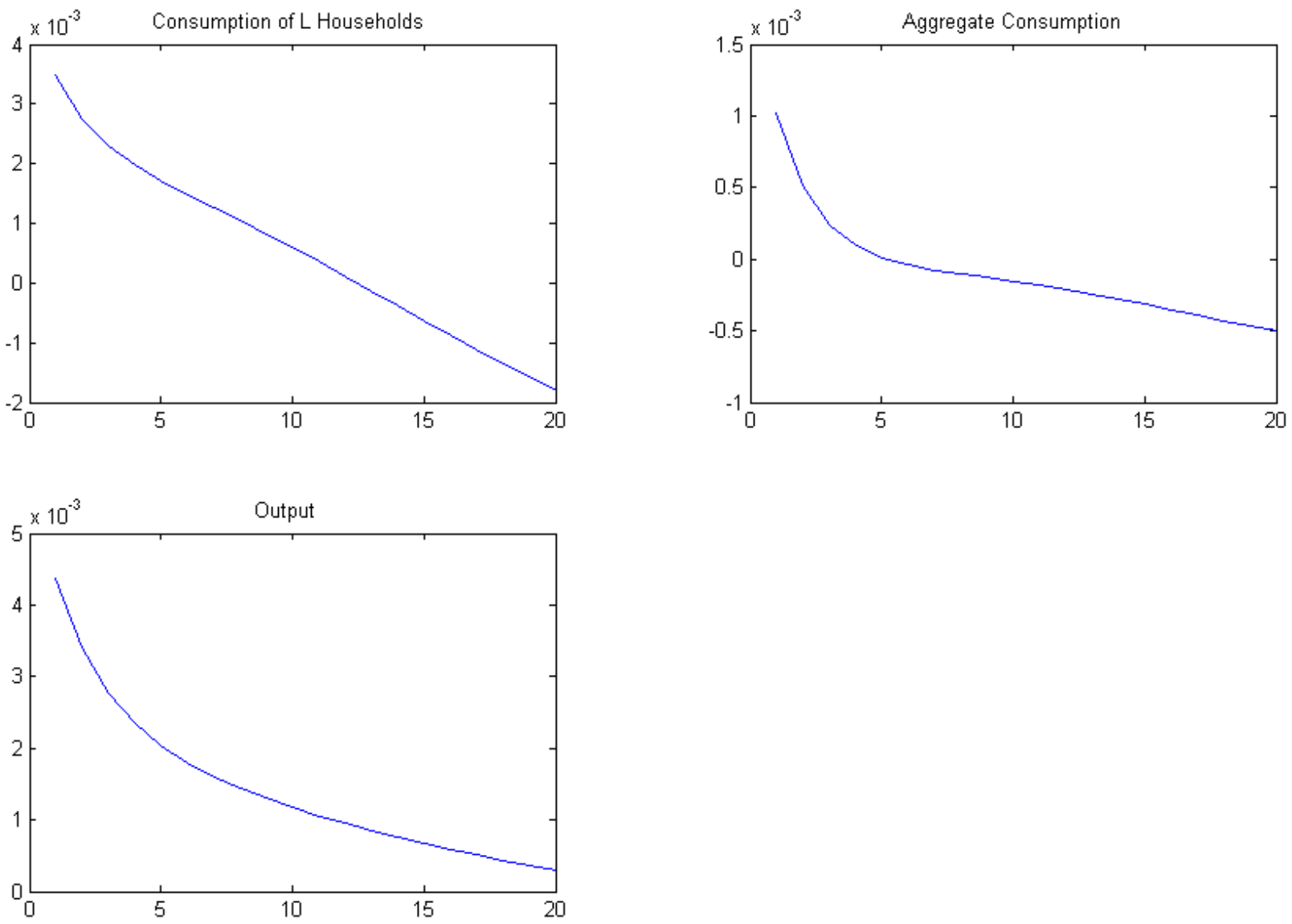